\title{
The Relationship between Diagenetic Evolution and Hydrocarbon Charge in Deep Tight Reservoirs: A Case Study from Kepingtage Formation of S9 Well Block in Tarim Basin
}

\author{
Yukai Qi, ${ }^{1}$ Huixi Lin $\mathbb{D}^{1}{ }^{1}$ Fushun Zhang, ${ }^{1}$ Xiuxiang $\mathrm{Zhu},{ }^{2}$ Hanwen Hu, ${ }^{1}$ Bo Zhou, ${ }^{1}$ \\ and Qing $\mathrm{Wei}^{3}$ \\ ${ }^{1}$ Research Institute of Petroleum Exploration and Production, Sinopec, Beijing, China \\ ${ }^{2}$ Northwest Oilfield Branch Company Ltd., Sinopec, Urumqi, China \\ ${ }^{3}$ Research Institute of Petroleum Exploration and Development, Petrochina, Beijing, China \\ Correspondence should be addressed to Huixi Lin; linhx80.syky@sinopec.com
}

Received 14 October 2020; Revised 3 February 2021; Accepted 20 March 2021; Published 9 April 2021

Academic Editor: Keyu Liu

Copyright ( 2021 Yukai Qi et al. This is an open access article distributed under the Creative Commons Attribution License, which permits unrestricted use, distribution, and reproduction in any medium, provided the original work is properly cited.

\begin{abstract}
The Silurian Kepingtage Formation of Tarim Basin is an important deep clastic reservoir. Exploration practice shows that the reservoirs are generally characterized by extremely low porosity and permeability, exhibiting strong mineral composition and physical property heterogeneities. The study of heterogeneity and its effect on oil charge is of great significance to the understanding of oil migration and accumulation in such reservoirs and thus is crucial to oil exploration. Therefore, based on identification and quantitative statistics of thin sections, SEM, and homogenization temperature measurements, this study was designed to examine the relationship between diagenetic evolution and oil emplacement in the Silurian Kepingtage Formation in S9 Block in Tarim Basin. The control of differential diagenesis and physical property evolution on oil charge process are discussed. It is found that the sandstones with fine grain size and high content of ductile grains $(>20 \%)$ have experienced strong mechanical compaction, the porosity decreases rapidly in the early stage of burial. The densification process has been completed before the first period of oil charge so that no oil was found in the reservoir. In contrast, sandstones with relatively coarse grain size and low ductile grain content have better porosity and permeability properties, which are generally oil-bearing. This kind of sandstone generally experienced two periods of oil charge. Apart from moderate compaction, multiple diagenesis events were also observed, including quartz cementation, calcite cementation, and dissolution. Before the early period of oil charge, the diagenesis events are dominated by moderate compaction, chlorite cementation, and dissolution, and the reservoir property is still high. It seems that the time of late period oil charge is relatively long. With the growth of multiple types of authigenic minerals such as quartz, calcite, and illite after or sometimes synchronously occurred with the late period oil charge, the porosity gradually decreases.
\end{abstract}

\section{Introduction}

With the development of global oil and gas industry, the exploration of oil and gas continues to extend to deep and ultradeep reservoirs. In recent years, exploration practice has proved that there are rich oil and gas resources in the deep reservoirs $[1,2]$. More than 1000 oil and gas fields with a depth of more than 4500 meters have been discovered worldwide $[3,4]$.

Under deep conditions, the formation and evolution of effective reservoirs have always been one of the key issues for deep hydrocarbon migration and accumulation [5]. With the increase of burial depth, the sedimentary strata experienced various diagenesis events. Therefore, the porosity and permeability properties of the reservoir are generally poor and the distribution of reservoir physical properties shows strong heterogeneity $[2,6]$.

Reservoir heterogeneity is the comprehensive result of original sedimentation, diagenesis, and tectonic movements $[7,8]$. Influenced by the original sedimentary structure and mineral composition, the diagenetic characteristics and diagenetic degree of different positions in the same sand body 


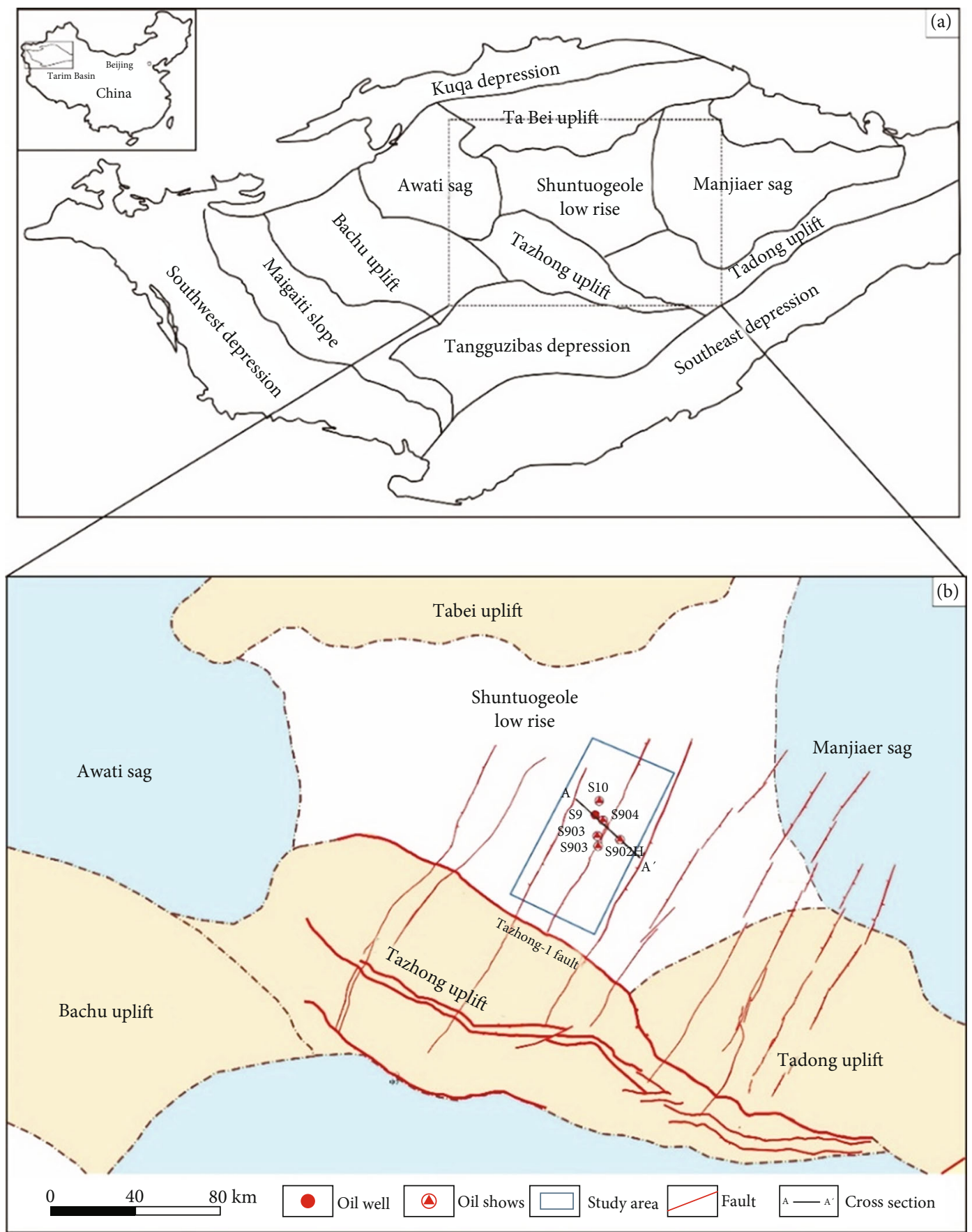

FIGURE 1: (a) Regional geological map showing the structure features of Tarim Basin and the location of the study area. (b) Location of the studied wells.

are completely different, resulting in different diagenetic evolution and porosity reduction process $[9,10]$. As a result, the permeable rocks in the reservoir are separated by low- or nonpermeability interlayers (such as fine-grained sandstone layer rich in ductile grains and tight cemented nodules of early carbonate). These low-permeability or impermeable rocks are distributed in accordance with certain sedimentary structures at different scales $[11,12]$. Due to the influence of these interbeds, the hydrocarbon migration behaviours in such heterogeneous reservoirs are extremely uneven and are far different from the traditional homogeneous reservoirs $[11,12]$. The study of heterogeneity and its effect on oil charge is of great significance to the oil migration and accumulation in such reservoirs and thus is crucial to oil exploration.

In recent years, industrial oil breakthrough has been achieved in Kepingtage Formation of Silurian in S9 well block in Tarim Basin. However, the overall burial depth of the Kepingtage Formation is generally between 5500 and 6500 meters. The physical properties of deep-buried 


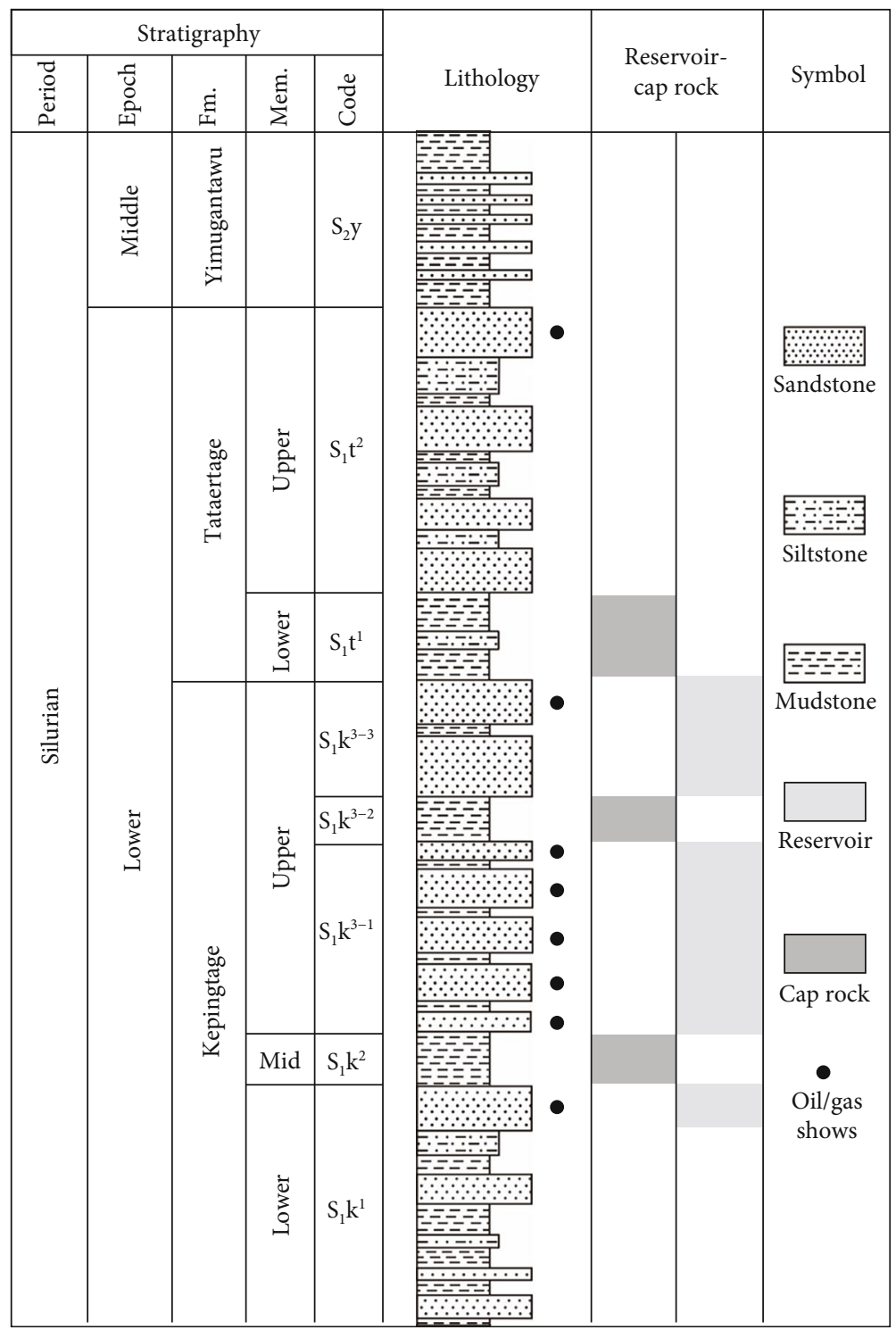

FIgUre 2: Generalized stratigraphic column of the Well S9 Block in Tarim Basin.

reservoirs are generally poor and highly heterogeneous. The characteristics and formation process of effective reservoirs are unclear, which affects further exploration deployment.

In this paper, the tight sandstone of the Silurian Kepingtage Formation in the S9 well block of Tarim Basin is taken as a research example. Based on thin section observation, SEM, and fluid inclusion analysis, the periods of hydrocarbon charge are studied and the main diagenesis events causing reservoir densification are analysed. In light of this, the relationship between oil emplacement and diagenetic evolution is determined and the formation and evolution of effective deep reservoirs is discussed.

\section{Geological Background}

Tarim Basin is located in northwest China, with an area of $56 \times 10^{4} \mathrm{~km}^{2}$. It is the largest petroliferous basin in inland China. From north to south, the basin is divided into seven major structural units: Kuqa depression, the Tabei uplift belt, the Northern depression belt (the Awati sag and Manjiaer sag), the Central uplift (the Bachu uplift, Tazhong uplift, and Guchengxu uplift), the Southwest depression belt, the Tadong uplift, and Southeast depression (Figure 1(a)). The study area is located in the southern part of the Shuntuoguole low uplift, adjacent to the Tabei Uplift in the north, Tazhong Uplift in the south, and Manjiaer sag in the east, which is a relatively stable paleostructural unit (Figure 1(b)).

The Shuntuoguole region has experienced multistage tectonic evolution. In the early Caledonian period (Cambrian to Middle Ordovician), the Shuntuoguole region was in the stage of weak extension within the craton and experienced regional stable tectonic subsidence [13]. In the middle Caledonian (Ordovician), the area is in the stage of craton uplift formation under compression. At the end of the Late Ordovician, Tazhong uplift and Tabei uplift on the north and south side of the Shuntuoguole low rise were fully formed, and the overall compression state lasted until the late Caledonian to early Hercynian (Silurian to Devonian) [14]. In the 


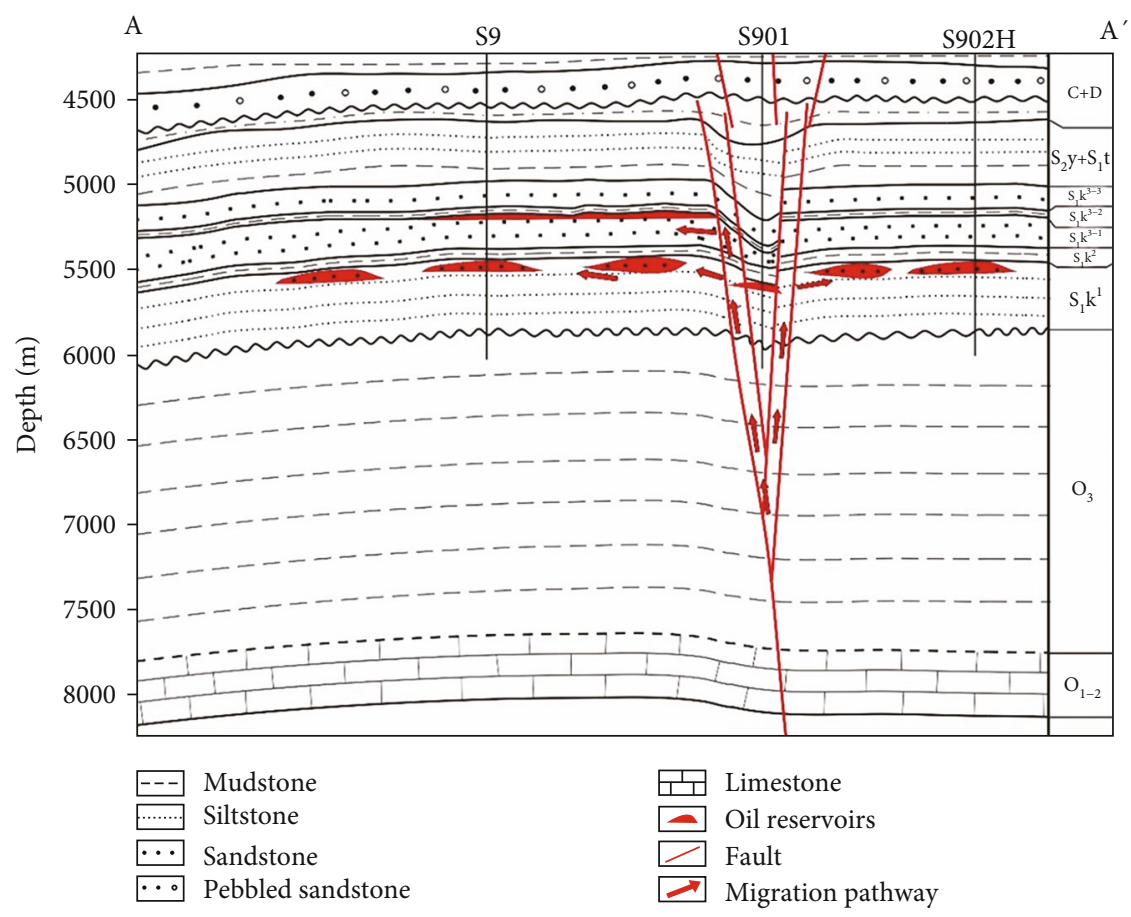

FIgURE 3: The oil migration and accumulation model in Silurian reservoirs of Well S9 Block. Location of the section is shown in Figure 1(b).

middle and late Hercynian (Carboniferous to Permian), affected by continuous uplift of Tabei uplift, the Shuntuoguole low rise was also further uplifted [15]. During Indosinian to Yanshanian (Triassic to Cretaceous), the Shuntuoguole region continued to be buried and the present structural pattern was formed in the Himalayan period $[15,16]$.

The Tarim Basin was in a stable subsidence period during Silurian in which coastal and shallow marine sandy clastic sedimentary system was developed [17-19]. The Silurian strata in the study area are Kepingtage formation, Tataertage formation, and Yimugantawu formation from bottom to top (Figure 2). The target strata of this study can be further subdivided into upper, middle, and lower members (Figure 2). During the sedimentary of the lower member $\left(S_{1} k^{1}\right)$, the strata on both the north and south side of the Tarim Basin were uplifted and eroded under the influence of the NorthSouth tectonic compressive stress. With sufficient terrigenous clastic supplies, the coastal to shallow shelf sedimentary system was developed in the study area [19]. During the sedimentary of the middle member $\left(S_{1} \mathrm{k}^{2}\right)$, the study area is dominated by shallow marine shelf mud affected by transgression [17], forming a good reservoir-cap assemblage with the lower member of the Kepingtage formation [20-22]. Shoreface and tidal flat sand bodies were developed in the upper member of Kepingtage formation, forming an ideal reservoir-cap assemblage with the red mudstone of the overlying Tataertag formation (Figure 2).

The study area is close to Manjiaer hydrocarbon generation sag, in which two sets of high-quality source rocks are developed: the Cambrian and the Lower Ordovician source rocks, providing superior oil source conditions [23, 24]. With multistage tectonic movements in the Tazhong area, the two source rocks experienced three peaks of hydrocarbon gener- ation and expulsion: Middle-Late Ordovician, Permian-Triassic, and Paleogene-Neogene. The first two stages are dominated by oil generation, while the later stage is dominated by gas generation [24]. Under the multistage tectonic movements, a series of NE trending strike-slip faults were developed in the study area (Figures 1(b) and 3), along which the deep oil and gas can migrate vertically and then migrate laterally in Silurian reservoirs [25-27].

\section{Methodology and Samples}

As oil discoveries are mainly located in the lower member of the Kepingtage Formation, therefore, only the $S_{1} k^{1}$ reservoir is targeted for detailed study in this paper. Based on the core observations of six wells (S9, S901, S902H, S903, S904, S10), twenty-four selective samples were collected regarding the differences between oil-bearing level and grain size. By means of porosity and permeability analysis, thin section, SEM, clay mineral X-ray diffraction, and homogenization temperature test of inclusions, the differences of petrology characteristics, diagenesis, and hydrocarbon charge of different oil-bearing reservoirs are analysed to clarify the origin of reservoir heterogeneity and the evolution process of Silurian Kepingtage formation.

Porosity determination was by helium injection and permeability to air under unstressed conditions. 24 samples are measured and 92 measurements are collected from the previous report by Sinopec.

All samples were impregnated with blue epoxy resin in a vacuum to remove gas from the samples. Modal point count analysis was carried out on all samples to investigate grain size, mineralogy, pore type, and pore volume (300 points in each section). Selected samples were examined for the habits 
TABLE 1: Summary point count data and sample petrophysical properties.

(a)

\begin{tabular}{|c|c|c|c|c|c|c|c|c|c|c|}
\hline \multirow[b]{2}{*}{ Well } & \multirow[b]{2}{*}{ Depth } & \multirow[b]{2}{*}{ Petrofacies } & \multicolumn{3}{|c|}{ Textural characteristic } & \multicolumn{3}{|c|}{ Thin section porosity (\%) } & \multicolumn{2}{|c|}{ Core measurement } \\
\hline & & & $\begin{array}{l}\text { Sorting } \\
\text { (class) }\end{array}$ & $\begin{array}{l}\text { Roundness } \\
\text { (class) }\end{array}$ & $\begin{array}{l}\text { Median grain size } \\
(\mu \mathrm{m})\end{array}$ & Total & Primary & Secondary & $\begin{array}{l}\text { Porosity } \\
\text { (\%) }\end{array}$ & $\begin{array}{c}\text { Permeability } \\
(\mathrm{mD})\end{array}$ \\
\hline S9 & 5578.95 & $\mathrm{~A}$ & $\mathrm{G}$ & SA-SR & 266 & 4.4 & 3.2 & 1.2 & 8 & 0.51 \\
\hline S9 & 5580.1 & $\mathrm{~B}$ & G & SA-SR & 164 & & & & 1.4 & 0.01 \\
\hline S9 & 5581.22 & A & M & SA-SR & 264 & 2.8 & 1.9 & 0.9 & 7.5 & 0.53 \\
\hline S9 & 5584.37 & A & G & SA-SR & 248 & 3.6 & 3 & 0.6 & 9 & 0.4 \\
\hline S9 & 5584.75 & A & G & SA-SR & 228 & 2.2 & 1.6 & 0.6 & 7.5 & 0.26 \\
\hline S9 & 5586.43 & B & G & SA-SR & 157 & & & & 2.3 & 0.05 \\
\hline S9 & 5605.41 & B & G & SA-SR & 159 & 0.3 & 0.3 & & 5.3 & 0.02 \\
\hline S901 & 5503.84 & B & G & SA-SR & 179 & & & & 2.9 & 0.02 \\
\hline S901 & 5508.72 & A & G & SA-SR & 220 & 0.5 & 0.5 & & 6.1 & 0.05 \\
\hline S901 & 5512.08 & A & G & SA-SR & 257 & 2.8 & 2 & 0.8 & 9.2 & 0.15 \\
\hline $\mathrm{S} 902 \mathrm{H}$ & 5516.07 & A & G & SA-SR & 264 & 0.7 & 0.7 & & 5.8 & 0.18 \\
\hline $\mathrm{S} 902 \mathrm{H}$ & 5522.31 & A & G & SA-SR & 221 & 1.2 & 0.7 & 0.5 & 7.51 & 0.09 \\
\hline $\mathrm{S} 902 \mathrm{H}$ & 5522.81 & A & G & SA-SR & 220 & 1.9 & 1.6 & 0.3 & 7.55 & 0.23 \\
\hline $\mathrm{S} 902 \mathrm{H}$ & 5517.17 & $\mathrm{~A}$ & M & SA-SR & 228 & 0.5 & 0.5 & & 5.4 & 0.23 \\
\hline $\mathrm{S} 902 \mathrm{H}$ & 5527.09 & $\mathrm{~A}$ & G & SA-SR & 208 & 1.2 & 0.9 & 0.3 & 7.7 & 0.09 \\
\hline $\mathrm{S} 902 \mathrm{H}$ & 5527.16 & $\mathrm{~A}$ & G & SA-SR & 200 & 0.5 & 0.5 & & 7.2 & 0.13 \\
\hline $\mathrm{S} 902 \mathrm{H}$ & 5528.79 & $\mathrm{~A}$ & G & SA-SR & 253 & 2.3 & 1.5 & 0.8 & 8.1 & 0.44 \\
\hline S903 & 5576.52 & B & G & SA-SR & 146 & & & & 2.1 & 0.11 \\
\hline S903 & 5580.36 & A & M & SA-SR & 230 & 1.3 & 0.7 & 0.6 & 7.4 & 0.84 \\
\hline S903 & 5593.97 & B & G & SA-SR & 153 & & & & 2.9 & 0.05 \\
\hline S903 & 5603.48 & A & G & SA-SR & 250 & 3.3 & 1.9 & 1.4 & 7.9 & 0.1 \\
\hline S904 & 5574.15 & A & G & SA-SR & 251 & 2.4 & 1.6 & 0.8 & 8.8 & 0.07 \\
\hline S904 & 5576.58 & $\mathrm{~A}$ & G & SA-SR & 225 & 2.1 & 1.4 & 0.7 & 8 & 0.2 \\
\hline S10 & 5692.86 & A & G & SA-SR & 220 & 1.7 & 1.5 & 0.2 & 7.8 & 0.15 \\
\hline
\end{tabular}

(b)

\begin{tabular}{|c|c|c|c|c|c|c|c|c|c|c|c|c|c|}
\hline \multirow{2}{*}{ Well } & \multirow{2}{*}{ Depth } & \multicolumn{5}{|c|}{ Detrital grains (\%) } & \multicolumn{3}{|c|}{ Authigenic minerals (\%) } & \multicolumn{4}{|c|}{$\begin{array}{c}\text { Clay minerals } \\
(\%)\end{array}$} \\
\hline & & Quartz & Feldspar & Rock fragment & Pseudomatrix & $\begin{array}{c}\text { Ductile } \\
\text { grains }\end{array}$ & $\begin{array}{c}\text { Quartz } \\
\text { overgrowth }\end{array}$ & Calcite & $\begin{array}{c}\text { Clay } \\
\text { minerals }\end{array}$ & $\mathrm{I} / \mathrm{S}$ & It & $\mathrm{C}$ & $\mathrm{I} / \mathrm{S}, \mathrm{S}$ \\
\hline S9 & 5578.95 & 42.1 & 8.5 & 49.4 & 2.5 & 16.1 & 2.1 & 0.3 & 1.5 & & & & \\
\hline S9 & 5580.1 & 28.1 & 5.8 & 66.1 & 25.6 & 28.6 & & & 5.0 & 25 & 24 & 51 & 20 \\
\hline S9 & 5581.22 & 40.5 & 3.8 & 55.7 & 4.8 & 12.8 & 2.1 & 1.0 & 1.0 & & & & \\
\hline S9 & 5584.37 & 48.6 & 6 & 45.4 & 3.3 & 11.6 & 0.7 & & & & & & \\
\hline S9 & 5584.75 & 38.4 & 7.2 & 54.4 & 5.5 & 15.4 & 2.0 & 0.8 & 2.0 & & & & \\
\hline S9 & 5586.43 & 31.4 & 2.3 & 66.3 & 16 & 25.7 & & & 4.5 & 50 & 24 & 26 & 20 \\
\hline S9 & 5605.41 & 30.7 & 6.8 & 62.5 & 14.6 & 24.1 & 0.2 & & 4.0 & 20 & 20 & 60 & 15 \\
\hline S901 & 5503.84 & 32.8 & 5.4 & 61.8 & 12.3 & 21.6 & & & 5.0 & 54 & 36 & 10 & 20 \\
\hline S901 & 5508.72 & 42.3 & 5.7 & 52 & 8.4 & 17.8 & 3.3 & 0.1 & 1.0 & 31 & 18 & 51 & 15 \\
\hline S901 & 5512.08 & 53.6 & 8.1 & 38.3 & 3.1 & 10.7 & 1.3 & & & & & & \\
\hline S902H & 5516.07 & 41.3 & 6 & 52.7 & 2.7 & 12.3 & 4.5 & & 2.0 & 46 & 29 & 17 & 20 \\
\hline S902H & 5522.31 & 37.5 & 8.1 & 54.4 & 4.5 & 16.7 & 1.6 & & 2.5 & 29 & 18 & 53 & 15 \\
\hline S902H & 5522.81 & 48.3 & 2.6 & 49.1 & 6.5 & 17.1 & 0.6 & & & 30 & 10 & 60 & 15 \\
\hline S902H & 5517.17 & 33.7 & 5.2 & 61.1 & 13.1 & 20.6 & 0.4 & 1.2 & 1.0 & 45 & 21 & 34 & 15 \\
\hline S902H & 5527.09 & 48.9 & 4.7 & 46.4 & 8.6 & 19.3 & 2.1 & & & & & & \\
\hline
\end{tabular}


TABLE 1: Continued.

\begin{tabular}{|c|c|c|c|c|c|c|c|c|c|c|c|c|c|}
\hline \multirow{2}{*}{ Well } & \multirow{2}{*}{ Depth } & \multicolumn{5}{|c|}{ Detrital grains (\%) } & \multicolumn{3}{|c|}{ Authigenic minerals (\%) } & \multicolumn{4}{|c|}{$\begin{array}{c}\text { Clay minerals } \\
(\%)\end{array}$} \\
\hline & & Quartz & Feldspar & Rock fragment & Pseudomatrix & $\begin{array}{c}\text { Ductile } \\
\text { grains }\end{array}$ & $\begin{array}{c}\text { Quartz } \\
\text { overgrowth }\end{array}$ & Calcite & $\begin{array}{c}\text { Clay } \\
\text { minerals }\end{array}$ & $\mathrm{I} / \mathrm{S}$ & It & $\mathrm{C}$ & $\mathrm{I} / \mathrm{S}, \mathrm{S}$ \\
\hline S902H & 5527.16 & 46.9 & 6.1 & 47 & 4.2 & 14.6 & 1.6 & & & & & & \\
\hline $\mathrm{S} 902 \mathrm{H}$ & 5528.79 & 52.3 & 5.9 & 41.8 & 3.3 & 11.8 & 3.1 & 0.5 & & & & & \\
\hline S903 & 5576.52 & 26.8 & 4.1 & 69.1 & 19.5 & 26.5 & & & & 34 & 33 & 33 & 20 \\
\hline S903 & 5580.36 & 46.4 & 7.2 & 46.4 & 2 & 12.9 & 2.1 & & 0.5 & 25 & 28 & 47 & 15 \\
\hline S903 & 5593.97 & 31.7 & 5.6 & 62.7 & 16.9 & 24.8 & & & & 20 & 13 & 67 & 15 \\
\hline S903 & 5603.48 & 49.5 & 5.7 & 44.8 & 4.1 & 14.3 & 2.0 & & & 26 & 14 & 60 & 15 \\
\hline S904 & 5574.15 & 49.3 & 4.9 & 45.8 & 5 & 13.8 & 1.8 & & 2.0 & & & & \\
\hline S904 & 5576.58 & 45.6 & 6.7 & 47.7 & 4.3 & 14.1 & 1.3 & 0.3 & 1.5 & & & & \\
\hline S10 & 5692.86 & 35.7 & 5.2 & 59.1 & 3.7 & 15.6 & 1.7 & & 1.0 & 22 & 20 & 58 & 15 \\
\hline
\end{tabular}

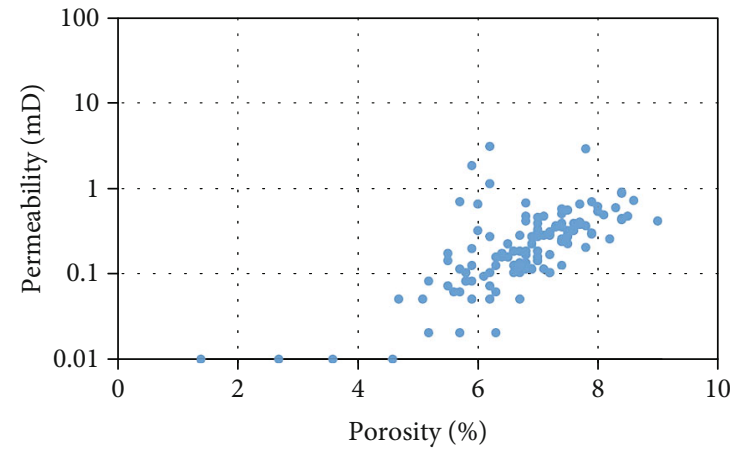

FIGURE 4: Reservoir physical properties of Kepingtage Formation.

of diagenetic minerals and textural relationships between diagenetic minerals using scanning electron microscopy (SEM).

X-ray diffraction analysis was undertaken on the $<2 \mu \mathrm{m}$ fraction of 14 samples to establish the clay mineralogy. Clay-fraction XRD analyses were run airdried, after solvation with ethylene glycol vapor overnight, and after heat treatment at $350^{\circ} \mathrm{C}$ for 2 hours.

All samples were made into $100-\mu \mathrm{m}$-thick doubly polished thin sections for oil-filled inclusions petrographic studies. By using incident ultraviolet light and transmitted white light with a Nikon 80I microscope, the pore bitumens (free oils and solid bitumens) and oil-filled inclusions were identified and classified. Their paragenetic sequences were also observed. The wavelength of the emission fluorescence is greater than $420 \mathrm{~nm}$. The fluorescence spectra of individual oil-filled inclusion were acquired using a HORIBA IHR320 Core3 miniature fiber optic spectrometer.

\section{Results and Analysis}

The petrology, structure, type, and content of authigenic minerals and physical properties of 24 core samples are tested. The results are shown in Table 1.

4.1. Physical Properties. The overall reservoir property of the reservoir is tight, with porosity of $1.4 \%-9.2 \%$ and average

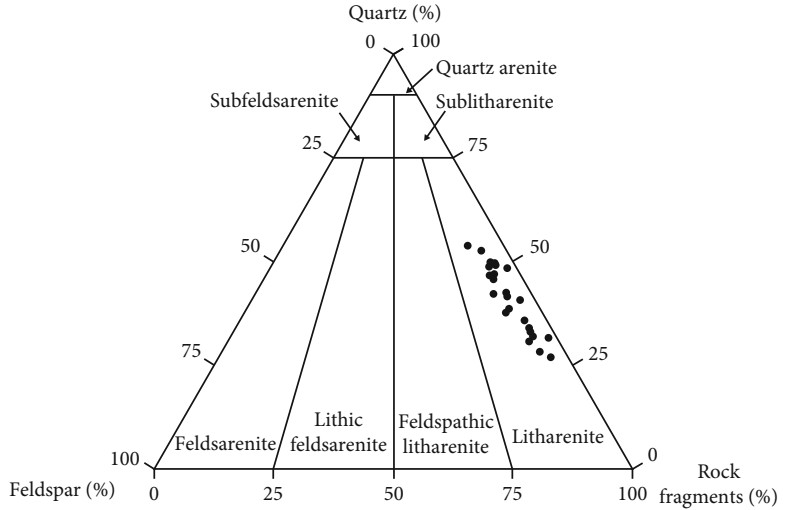

FIgURE 5: Sandstone QFL triangular classification [28] of the Kepingtage Formation.

value of $6.3 \%$, permeability of $0.01-2.84 \times 10^{-3} \mu \mathrm{m}^{2}$ with an average value of $0.38 \times 10^{-3} \mu \mathrm{m}^{2}$ (Table 1 and Figure 4). The present thin section porosity is low $(0-4.4 \%)$, and the pore type is mainly residual primary intergranular pore $(0.2-3.2 \%)$, which is generally irregular triangle or polygon. In addition, some intergranular and intragranular dissolution pores are developed, but the proportion is relatively low $(0.2-1.4 \%)$.

4.2. Petrology. According to the thin section identification and statistical analysis of the above samples, the lower member of the Silurian Kepingtage formation in the study area are all classified as litharenite using the classification of Folk [28] (Figure 5). The average content of detrital quartz grains is $40.9 \%$, which is dominated by single crystal quartz and a small amount of polycrystalline quartz and chert. The rock fragment has an average content of 53.3\%, mainly comprised of metamorphic rock fragments and sedimentary rock fragments, indicating the composition maturity is relatively low. The content of feldspar is low, with an average content of $5.7 \%$. The sandstones are mainly fine-grained, and the median grain size is $146-266 \mu \mathrm{m}$. Sorting varied from good to medium, and the roundness is generally subangular to subrounded (Table 1). 
TABle 2: Summary of reservoir characteristics of Petrofacies A and B.

\begin{tabular}{lcccccc}
\hline Petrofacies & Median grain size $(\mu \mathrm{m})$ & Ductile grains $(\%)$ & Pseudomatrix $(\%)$ & Porosity $(\%)$ & Permeability $(\mathrm{mD})$ & Oil beaing \\
\hline A & $200-266(236)$ & $10.7-20.6(14.8)$ & $2-13.1(4.9)$ & $5.4-9.2(7.5)$ & $0.05-0.84(0.14)$ & Yes \\
B & $146-179(160)$ & $21.6-28.6(25.2)$ & $12.3-19.5(16.0)$ & $1.4-5.3(2.6)$ & $0.01-0.11(0.04)$ & No \\
\hline
\end{tabular}

* The format in Table 2 is minimum-maximum (median).

4.3. Diagenesis. Based on the observation of petrology, physical property, and diagenesis of 24 samples, two sandstone petrofacies have been recognized (Table 1) according to the differences of reservoir physical properties, oil-bearing, ductile grain content, and diagenesis type and degree (Table 2). Petrofacies A sandstones are all oil-bearing with relatively good physical properties, coarser grain size, and ductile grain content less than $20 \%$, in which multistage and multitype diagenesis occurred. However, the physical properties of Petrofacies B are generally poor and no oil show was found. They are relatively fine grain size and have ductile grain content of more than $20 \%$, and thus, the diagenesis of these sandstones is dominated by strong compaction.

4.3.1. Petrofacies A. Petrofacies A sandstones are mainly fine to medium grained, with the median grain size values of 200$266 \mu \mathrm{m}$. In Petrofacies A sandstones, the thin section porosity ranges from $0.5 \%$ to $4.4 \%$. The pore types are mainly residual intergranular pores (0.5-3.2\%), and a small number of secondary porosity $(0.2-1.4 \%)$ are developed, which are mainly composed of intragranular dissolution pores of minerals such as feldspar and rock fragment (Figures 6(a), 6(b), $7(\mathrm{a})$, and $7(\mathrm{~b})$ and Table 1). It is found that the content of ductile grains in Petrofacies A is less than $20 \%$. It could be seen that some ductile grains (i.e., metamorphic rock fragments) are strongly compacted and deformed, blocking the primary intergranular pores (Figure 6(a)).

In Petrofacies A sandstones, authigenic minerals are dominated by quartz overgrowth $(0.2-4.8 \%)$, clay minerals (0.5-5.0\%), and calcite cement (0.1-1.2\%) (Table 1). Quartz overgrowth is very common in the study area. They often grow around detrital quartz grains with thickness varies from a few microns to tens of microns (Figures 6(b)-6(h)). In some cases, it can be seen that the quartz overgrowth could grow thick enough so that part of the overgrowth is located in adjacent rock fragment dissolution pore (Figures 6(c) and $6(\mathrm{~d})$ ), indicating that there is at least one stage of dissolution prior to the quartz precipitation.

Calcite cements are often patchy filled in primary intergranular pores (Figures 6(c), 6(d), 6(g), and 6(h)). Sometimes, they could also occur as grain replacements of feldspars, rock fragments, and quartz overgrowths (Figures 6(c), 6(d), and 7(c)). Most microscopic petrological evidence indicates that calcite precipitated after the quartz overgrowth (Figures 6(c) and 6(d)), but in a few cases, the lattice defect of quartz overgrowth can be seen due to the calcite preoccupied the pore space (Figure 6(g)). It is suggested that these two authigenic minerals exhibit a competitive growth relationship and precipitation may occur at the same time.
The X-ray diffraction analysis of clay minerals shows that the main clay minerals are chlorite, illite, and mixed layers of illite-smectite (Table 1). The relative content of chlorite ranges from $17 \%$ to $60 \%$ (Table 1), which mainly occurs as grain riming. Most of the chlorite grain rims underlie quartz overgrowth (Figure 6(e)). SEM results showed that although the surface of the quartz is coated by chlorite rims, the growth of quartz cement was not prevented (Figure 7(d)). The chlorite rims also developed on the surface of quartz overgrowths or rock fragments (Figures $7(\mathrm{e})$ and $7(\mathrm{f})$ ), indicating that there were two stages of chlorite precipitation and the second stage of chlorite film formed later than quartz overgrowth. The relative content of illite is mainly 10-29\% (Table 1). The illite is often filled in pores or attached to the grain surfaces in flaky or fibrous form (Figure $7(\mathrm{~g})$ ). The relative content of mixed layers of illite-smectite is $22-46 \%$ (Table 1 ), which is mainly attached on grain surface or as pore fillings (Figure 7(h)).

4.3.2. Petrofacies B. The grain size of Petrofacies B sandstone is generally fine with median grain size of $146-180 \mu \mathrm{m}$ (Figures 6(i) and 6(j)), reflecting weak hydrodynamic conditions during deposition. As a result, the ductile grain content is higher than $20 \%$ with a maximum number of $28 \%$. The ductile grains are mainly comprised of low-grade metamorphic rock fragments and mica. The overall capacity of compaction resistance of Petrofacies B sandstones is relatively weak compared with Petrofacies A sandstones. Therefore, the diagenesis is dominated by strong compaction. There is no obvious thin section porosity (core test porosity is less than 5\%) (Table 1). It is often seen that the mineral grains in Petrofacies B sandstones are distributed directionally under strong compaction, and some ductile grains are squeezed into the pores to form pseudomatrix (Figures 6(i) and $6(j))$. Therefore, the content of pseudomatrix in this kind of reservoir is higher than that in sandstone of Petrofacies A (Table 1). As the majority of pores in this kind of sandstone are destroyed by compaction, there are no other authigenic minerals except clay minerals. X-ray diffraction analysis of clay minerals shows that chlorite, illite, and mixed layers of illite-smectite are the main clay minerals in Petrofacies B (Table 1), with relative contents of $10-67 \%, 13-36 \%$, and 20-54\%, respectively.

4.4. Pore Bitumens and Oil-Filled Inclusions. The oil shows of the two types of sandstone are quite different. There is no hydrocarbon fluorescence displayed in Petrofacies B sandstone, indicating that hydrocarbon charge has never occurred. On the contrary, there are various hydrocarbon shows in the Petrofacies A sandstones. It can be seen that solid bitumens and oil asphaltenes exist in different forms. 


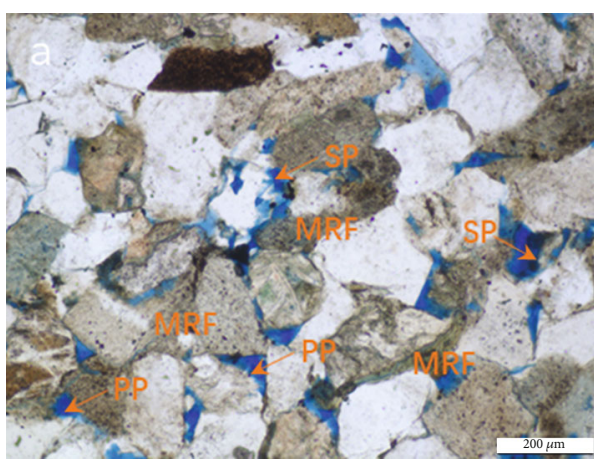

(a)

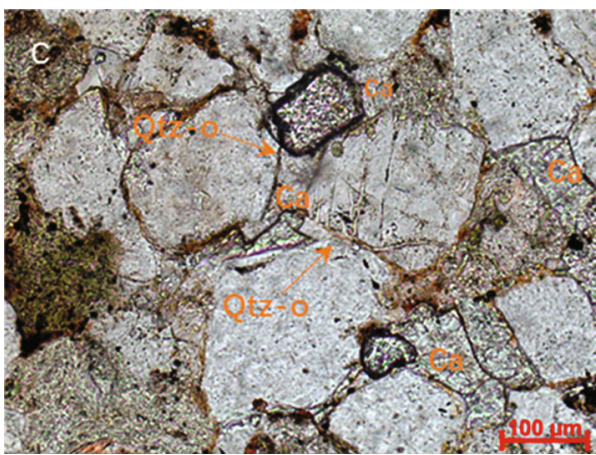

(c)

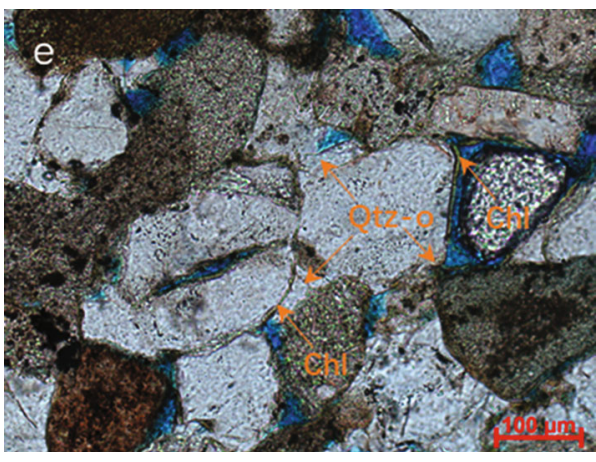

(e)

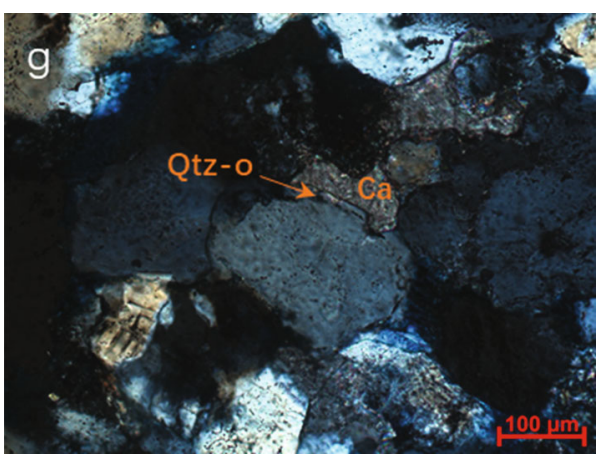

(g)

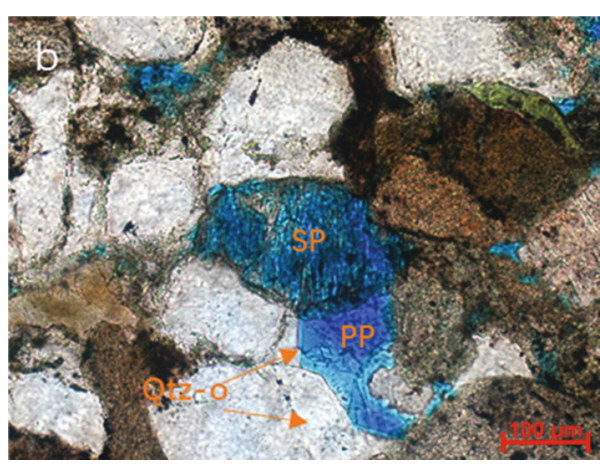

(b)

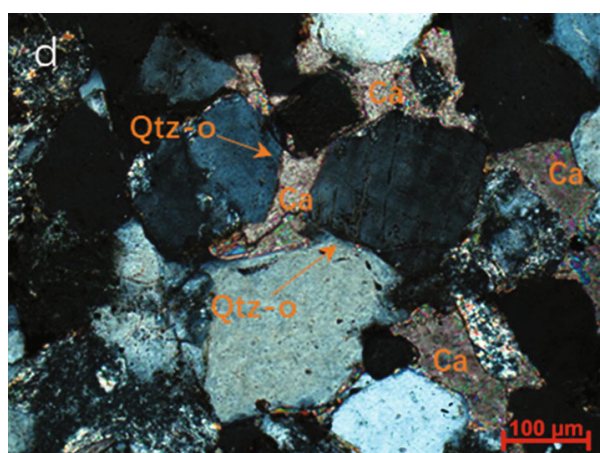

(d)

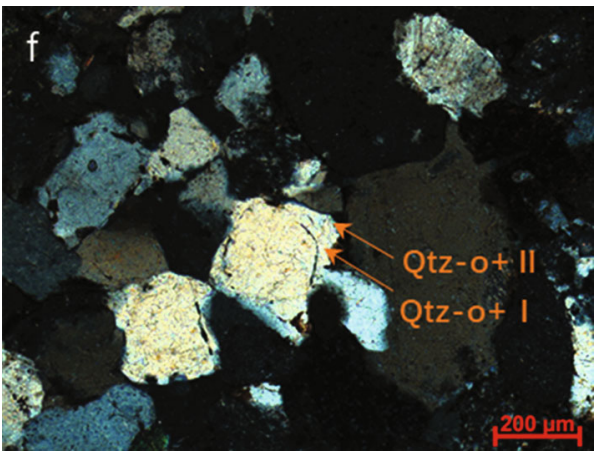

(f)

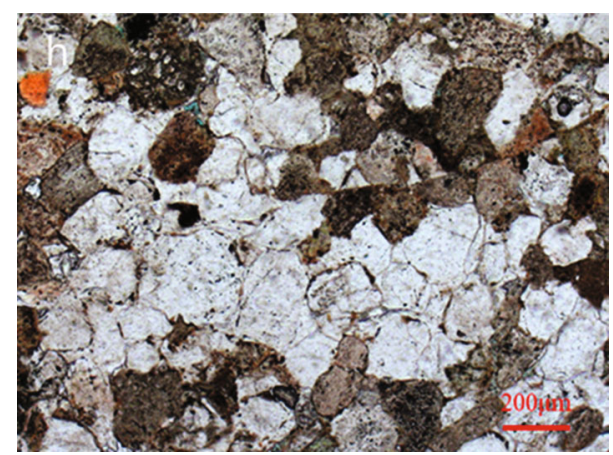

(h)

FIgure 6: Continued 


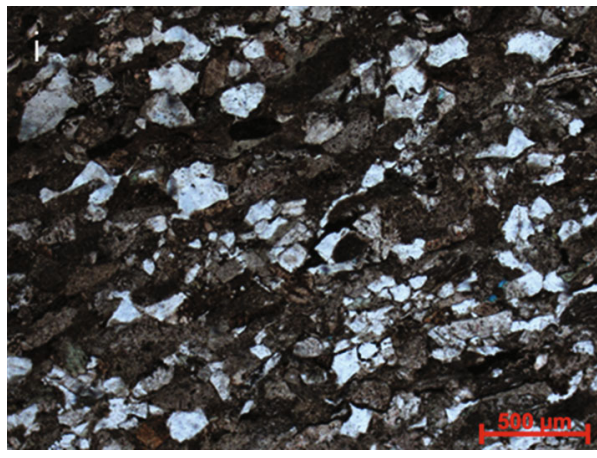

(i)

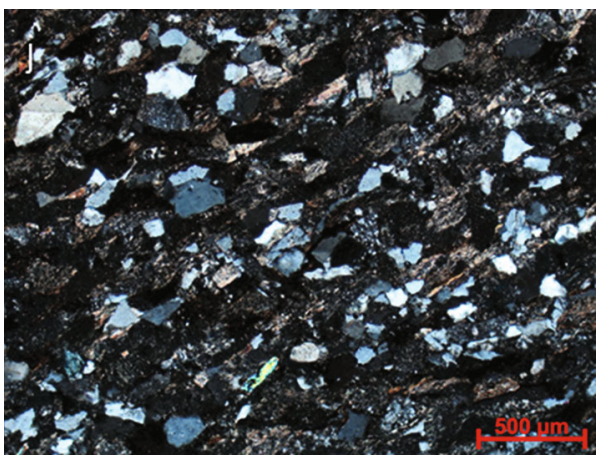

(j)

FIGURE 6: Optical photomicrographs of sandstones (pore space is indicated in blue). (a) Sample 5583.47, well S9: the reservoir is dominated by primary pores, note there are some metamorphic rock fragments which are extruded and deformed under compaction, blocking the primary pores. (b) Sample 5580.36, well S903: partially dissolution of feldspar grain forming secondary porosity, note the quartz overgrowths are occupying primary pores. (c, d) Sample 5516.07, well S901, plane-polarized light and cross-polarized light, respectively: the quartz overgrowth is located in adjacent rock fragment dissolution pore and then partially replaced by later calcite cement. (e) Sample 5580.36, well S903: chlorite developed as grain coating rims and engulfed by quartz overgrowths. (f) Sample 5692.86, well S10, two phases of quartz overgrowths. (g) Sample 5528.79, well S902H: lattice defect of quartz overgrowth can be seen due to the calcite cement preoccupied the pore space. (h) Sample 5516.07, well S901: intense quartz overgrowth and no visible thin section porosity is observed. (i, j) Sample 5580.1, well S9, plane-polarized light and cross-polarized light, respectively: the grains are distributed directionally under strong compaction, and some ductile grains are squeezed into the pores to form pseudomatrix. Key: quartz (Qtz), metamorphic rock fragment (MRF), quartz overgrowth (Qtz-o), Calcite $(\mathrm{Ca})$, Chlorite $(\mathrm{Chl})$, primary porosity $(\mathrm{PP})$, secondary porosity $(\mathrm{SP})$.

4.4.1. Oil Inclusion Petrography. Abundant free oil asphaltenes and solid bitumens are observed in Petrofacies A sandstones. The solid bitumens are black and opaque under transmitted light and are nonfluorescent under UV light. They are mainly filled in primary pores and dissolved cleavage cracks of feldspar grains (Figures $8(\mathrm{a})$ and $8(\mathrm{~b})$ ). They also occur as inclusions in quartz overgrowth (Figures 8(e) and $8(\mathrm{f})$ ) and calcite cement (Figures $8(\mathrm{~g})$ and $8(\mathrm{~h})$ ), indicating that the solid bitumen exists before the precipitation of quartz and calcite cement. The oil asphaltenes are black under transmitted light and yellow-white and blue under UV light with dominant fluorescence color of yellow-white. Similar as the solid bitumens, these oil asphaltenes are commonly seen in residual primary pores or adsorbed on the surface of feldspars and rock fragments (Figures $8(a)-8(d)$ ).

Apart from free oil asphaltenes, the oil inclusions were also found in authigenic minerals. The size of these oil inclusions is generally between 5 and $10 \mu \mathrm{m}$, a few of them are larger than $10 \mu \mathrm{m}$, and the gas-liquid ratio is between $5 \%$ and $10 \%$. The yellow-white fluorescent oil inclusions are the most common. They occur in large quantities in quartz overgrowth and calcite cement (Figures $8(\mathrm{e})-8(\mathrm{~h})$ ), indicating that oil charge occurred before or at least during cementation. It should be noted that sometimes solid bitumens and yellow-white fluorescent oil inclusions are simultaneously trapped in the same quartz overgrowth (Figures 8(e) and $8(\mathrm{f})$ ) or calcite cement (Figures $8(\mathrm{~g})$ and $8(\mathrm{~h})$ ). The content of blue fluorescent oil inclusions is less; they are often captured as thin oil films or single inclusion in quartz overgrowth (Figures $8(\mathrm{i})$ and $8(\mathrm{j})$ ). No blue fluorescent oil inclusion is found in calcite cement.

UV-visible microfluorescence spectra of single oil inclusion from representative samples are presented in Figure 8. It can be seen that the fluorescence spectrum characteristics of oil inclusions diverse with different fluorescence colors (Figure 9). Microfluorescence spectra of yellow-white fluorescent oil inclusions have a maximal intensity wavelength $(\lambda \max )$ at approximately $550-560 \mathrm{~nm}$, whereas the spectra of blue fluorescent oil inclusions have a $\lambda \max$ at $480-500 \mathrm{~nm}$.

4.4.2. Fluid Inclusion Microthermometry. In this study, based on the observation of hydrocarbon inclusions, the homogeneous temperature of gas-liquid two-phase aqueous fluid inclusions associated with oil inclusions were measured. As shown in Figure 9, the homogenization temperature of aqueous inclusions associated with hydrocarbon inclusions in the Kepingtage Formation is between 60 and $130^{\circ} \mathrm{C}$. However, the homogenization temperature of aqueous inclusions associated with oil inclusions of different fluorescence colors varies (Figure 10). The temperature of aqueous inclusions associated with yellow-white fluorescent oil inclusions is between 60 and $130^{\circ} \mathrm{C}$ with peaks at $90-100^{\circ} \mathrm{C}$. The homogenization temperature of aqueous inclusions associated with blue fluorescent oil inclusions is between 70 and $130^{\circ} \mathrm{C}$ with peaks at $100-110^{\circ} \mathrm{C}$. The temperature of aqueous inclusions associated with solid asphalt was not measured.

\section{Discussion}

The heterogeneity of sedimentary reservoirs is very common and many previous studies have been conducted [29, 30]. However, when it comes to petroleum exploration-oriented reservoir petrology, such heterogeneity is mostly covered up by simple statistical analysis. For example, as shown in Table 1, the test results of Kepingtage Formation in our study are basically consistent with those observed by previous scholars [31, 32]. However, many different understandings have been obtained when we divided the reservoir into two 


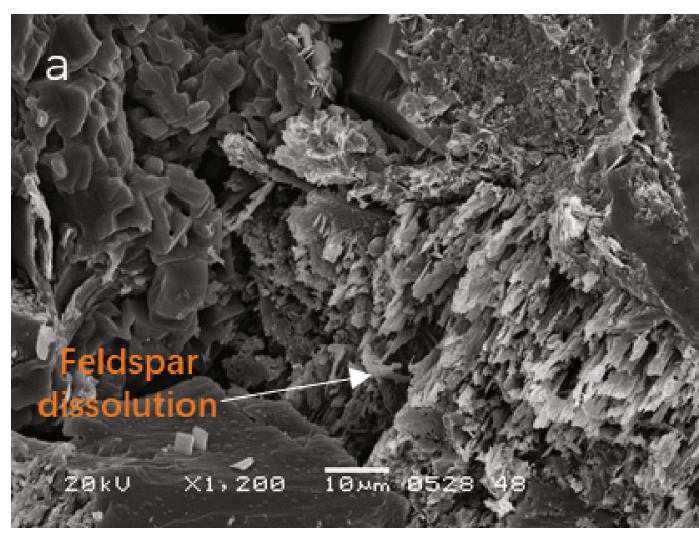

(a)

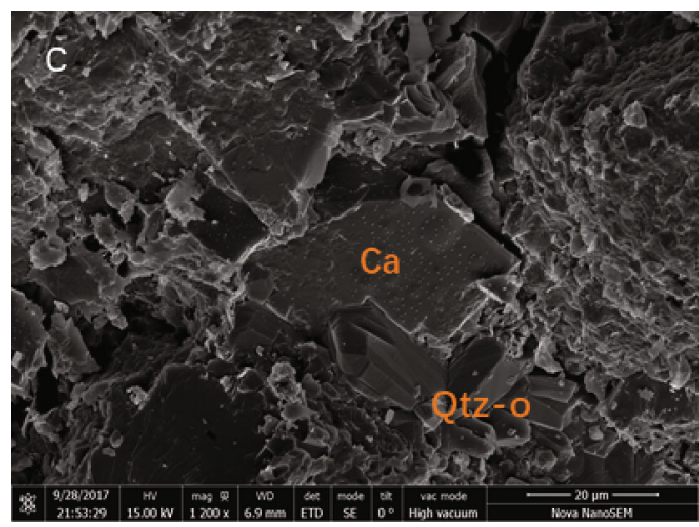

(c)

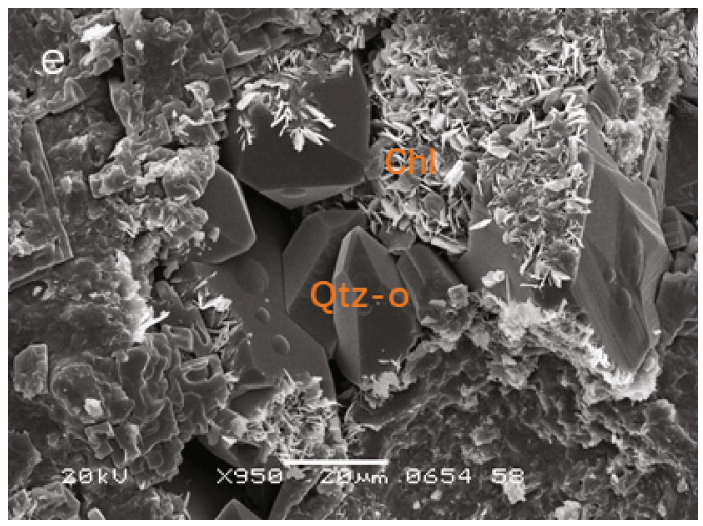

(e)

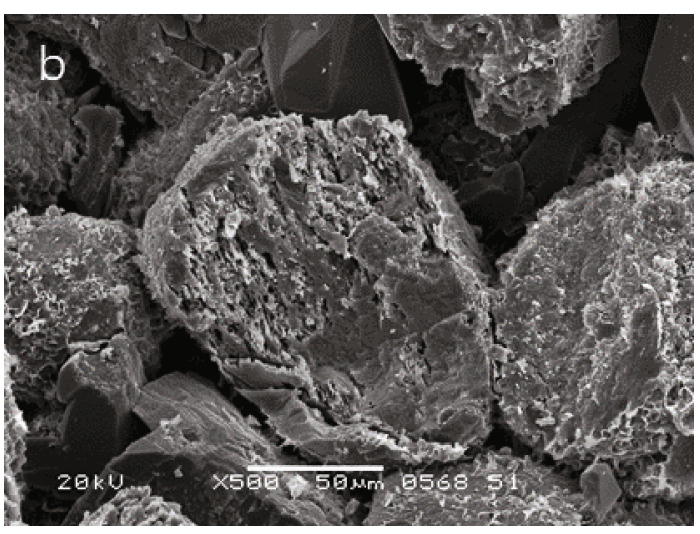

(b)

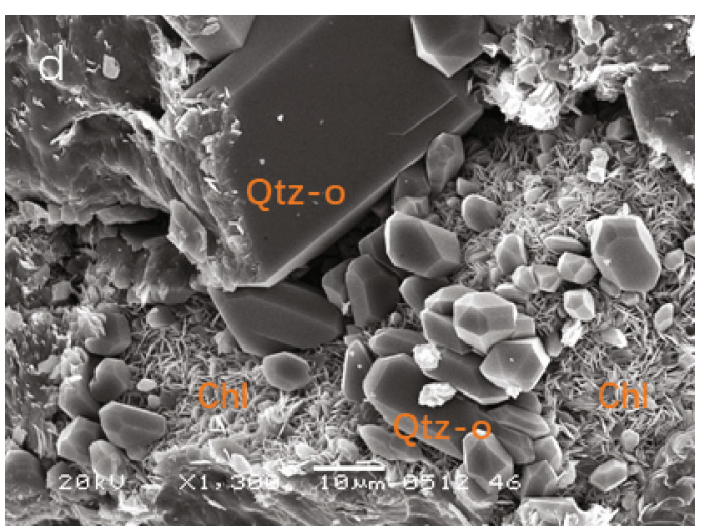

(d)

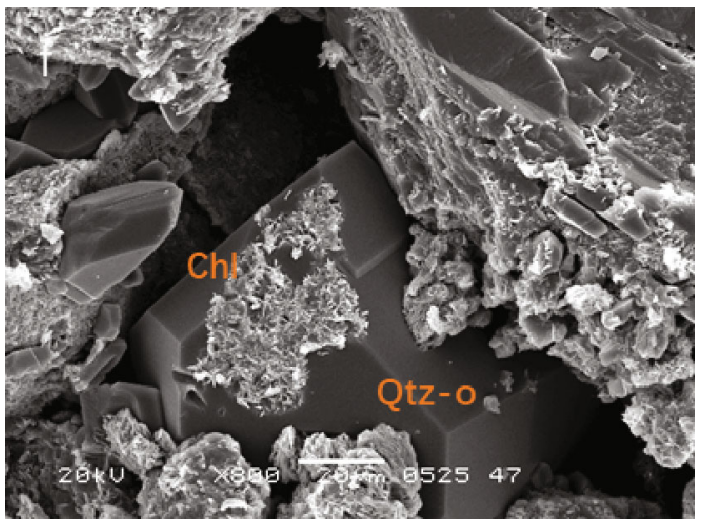

(f)

FIgURE 7: Continued. 


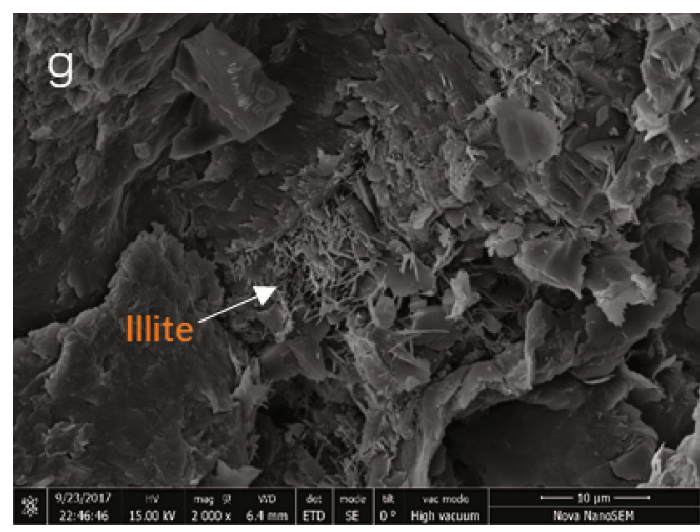

(g)

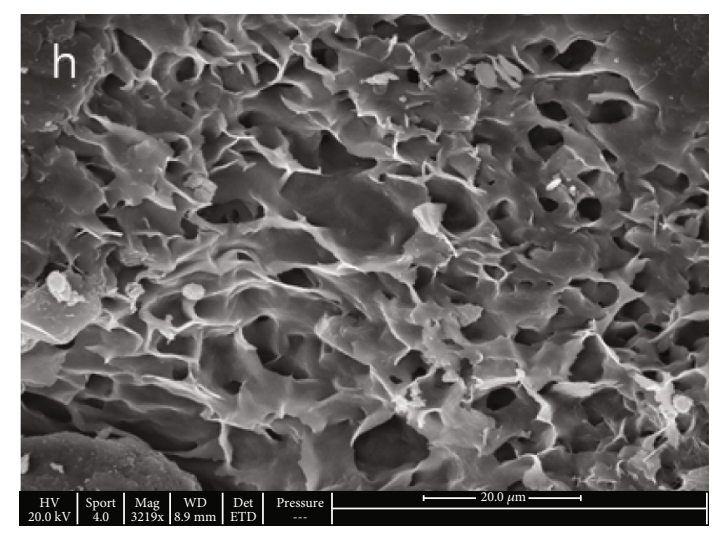

(h)

Figure 7: (a) Sample 5581.22, well S9, dissolved cleavage cracks of feldspar grain. (b) Sample 5508.72, well S901, partially dissolved feldspar grain. (c) Sample 5528.75, well S902H: quartz overgrowth occurs before calcite cement. (d) Sample 5584.75, well S9: the chlorite occurs as grain rimming and engulfed by quartz overgrowth. (e) Sample 5508.72, well S901: the quartz overgrowths are filled in the intergranular pores, and the chlorite is attached on the surface quartz overgrowth. (f) Sample 5584.75, well S9, chlorite film developed on quartz overgrowth. (g) Sample 5516.07, well S902H: occurrence of platy and fibrous illite. (h) Sample 5586.43, well S9: mixed layers of illitesmectite. Key: quartz overgrowth (Qtz-o), calcite (Ca), chlorite (Chl).

petrofacies sandstones and made observation and statistical analysis of the two sandstones individually.

5.1. Oil Charge History. Through the observation of fluorescence color of free oils and oil inclusion in the reservoir, it is found that there are three types of asphalt in the reservoir: nonfluorescent solid bitumen, yellow-white fluorescent, and blue fluorescent oil asphaltenes. The alternate occurrence of solid bitumens and oil asphaltenes in different authigenic minerals indicates that the reservoir may have experienced multiple stages of oil charge [33, 34]. Although the homogenization temperature of aqueous fluid inclusions associated with nonfluorescent solid bitumens was not measured, it is generally recognized by previous studies that the solid bitumens are the product of the destruction of paleooil reservoirs in late Caledonian (late Silurian) $[33,35,36]$. In the late Caledonian period, the strata in Tazhong area were uplifted and strongly eroded due to the north-south tectonic compressional stress [11]. The preexisted oil reservoirs have been uplifted to the surface and experienced strong water washing, oxidation, and biodegradation. The oils in the reservoir are finally evolved to the nonfluorescent black solid bitumen [35], which represent the earliest stage of oil charge.

The fluorescence color of oil asphaltene is closely related to its physical and chemical properties. With the increase of oil maturity, the fluorescence color of oil asphaltene changes in turn from yellow-white to yellow-green and then to blue [37]. The difference of maturity is also reflected in the UVvisible microfluorescence spectra of oil inclusions. With the decrease of $\lambda \max$, the fluorescence color of petroleum inclusions appears blue shift, which indicates that the oil maturity of inclusions increases. Conversely, with the increase of $\lambda \max$, the redshift phenomenon appears and the maturity decreases [38]. As shown in Figure 10, the $\lambda \max$ of blue fluorescent oil inclusions is mainly distributed in the range of $480-500 \mathrm{~nm}$, which is generally smaller than that of yellow- white fluorescent oil inclusions, indicating that the maturity of blue fluorescent oil inclusions is relatively high.

However, it cannot be determined that the two oil asphaltenes with different fluorescence colors represent two periods of oil charge. The homogenization temperature test results show that the homogenization temperatures of aqueous fluid inclusions associated with these two fluorescent oil inclusions are not significantly different (Figure 10), indicating that the charge time of the two oil inclusions is relatively close. However, the peak homogenization temperature of aqueous inclusions associated with blue fluorescent oil inclusions is slightly higher than that of yellow-white fluorescent oil inclusions (Figure 10). According to the occurrence sequence of authigenic minerals and oil inclusions, it can be seen that the blue fluorescent oil inclusions are captured in the second phase of quartz overgrowth, while the yellow-white fluorescent oil inclusions are trapped in the first phase of quartz overgrowth, which may indicate that the blue fluorescent oil charge occurs later (Figures $8(\mathrm{i})$ and $8(\mathrm{j})$ ). Combined with the previous research on thermal and burial history in the northern slope of Tazhong $[33,36]$, it can be seen that the charge time of yellow-white fluorescent asphaltenes and blue fluorescent asphaltenes is obviously different, but it is difficult to divide them into different periods. Therefore, it is considered that there are two episodes of oil charge in the same period of late Hercynian (Figure 11). Therefore, we believe that the Silurian Kepingtage formation has experienced two periods and three episodes of oil charge: late Caledonian and late Hercynian.

\subsection{Relationships between Diagenetic and Hydrocarbon} Charge. Among all the samples collected in the study area, only the Petrofacies A sandstones have experienced multiple types of diagenesis and multiple periods of oil charge. In order to clarify the type of reservoir diagenesis and the physical properties during the key oil charging period, different periods of oil charges were used as time marks to analyse 


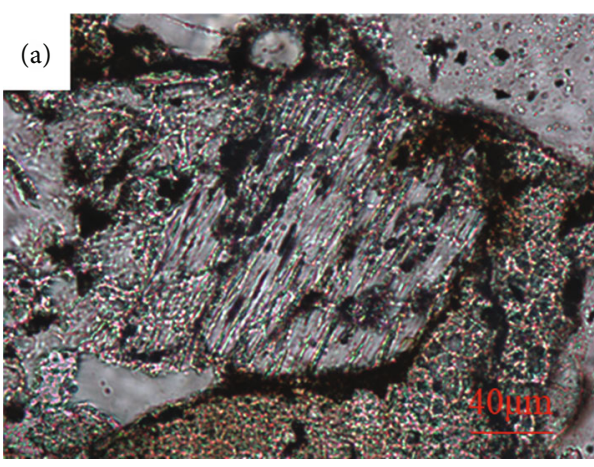

(a)

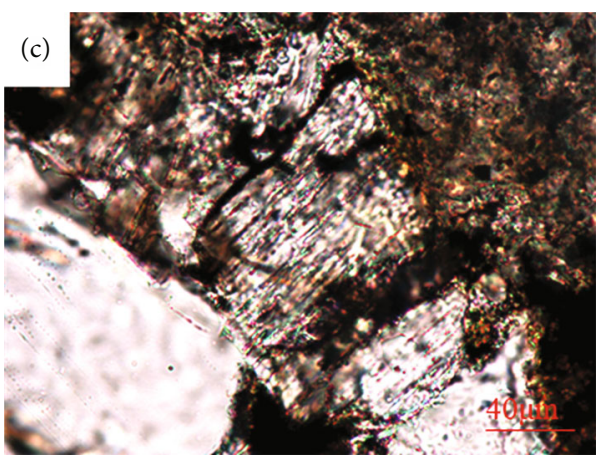

(c)

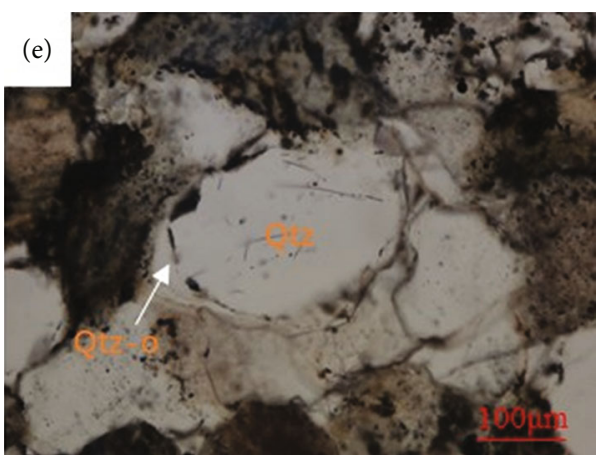

(e)

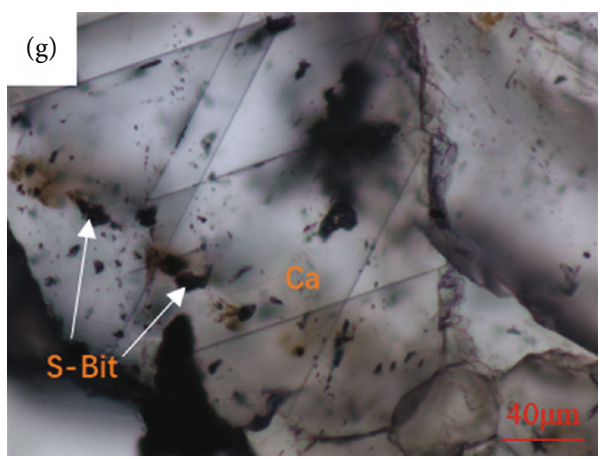

(g)

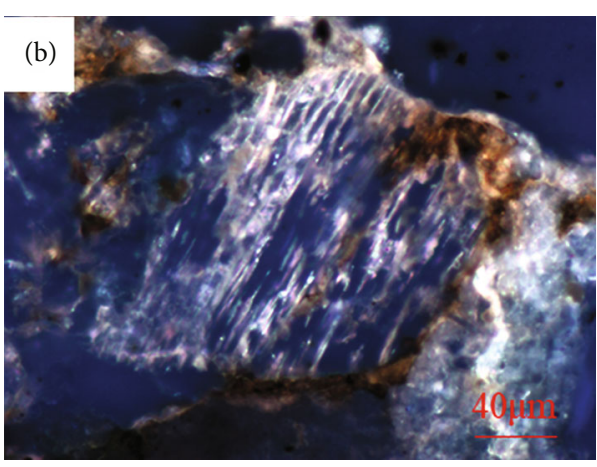

(b)

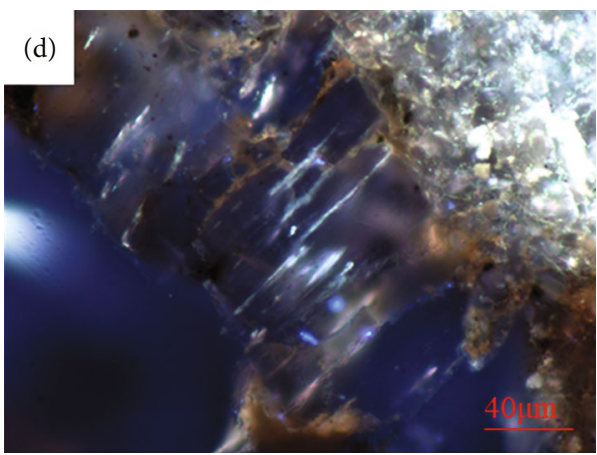

(d)

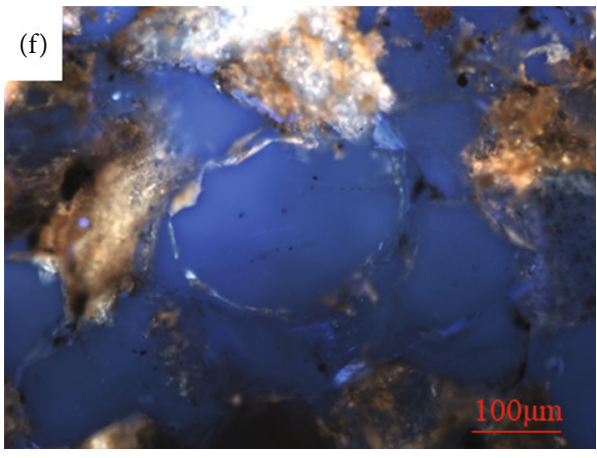

(f)

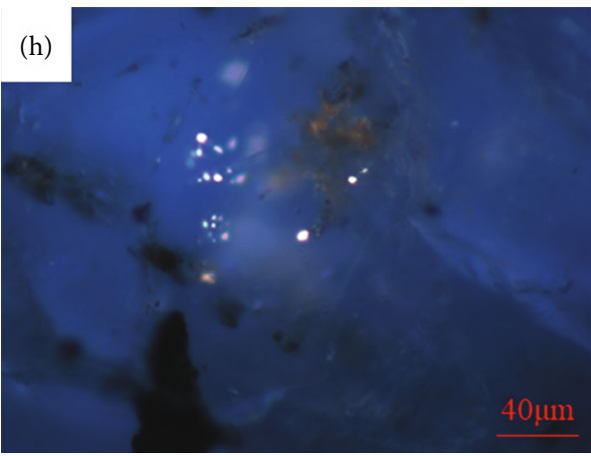

(h)

FIGURe 8: Continued. 


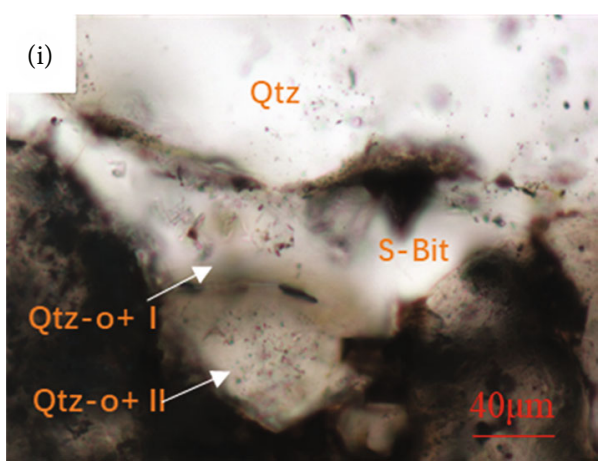

(i)

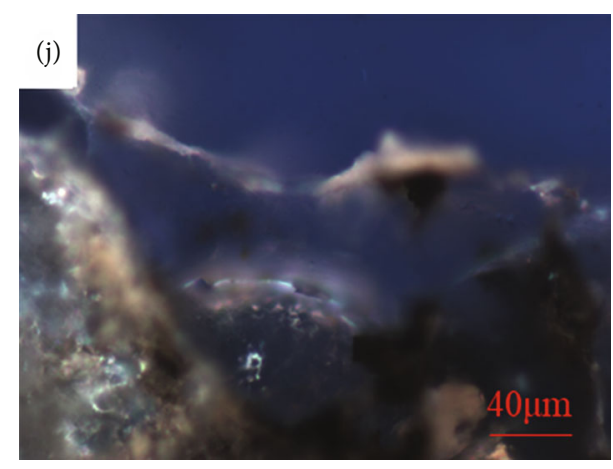

(j)

FIGURE 8: Optical photomicrographs of oil asphaltenes and solid bitumens under transmitted light (left) and UV light (right). (a, b) Sample 5603.48, well S903, black solid bitumen and yellow-white fluorescent free oils charged along dissolved cleavage cracks of feldspar grains; (c, d) Sample 5584.75, well S9, blue fluorescent free oils charged along dissolved cleavage cracks of feldspar grains. (e, f) Sample 5517.17, well $\mathrm{S} 902 \mathrm{H}$, black solid bitumens, and yellow-white fluorescent oil films were found in the same quartz overgrowth. (g, h) Sample 5580.36, well S903, black solid bitumen, and yellow-white fluorescent oil inclusions were captured in calcite cement. (i, j) Sample 5512.08 well S901, two phases of quartz overgrowth are observed, black solid bitumen and yellow-white fluorescent oil film coexist in the first phase of quartz overgrowth while in the second phase of quartz overgrowth the blue fluorescent oil film and inclusions were observed. Key: quartz overgrowth (Qtz-o), calcite (Ca), S-Bit (Solid bitumen).
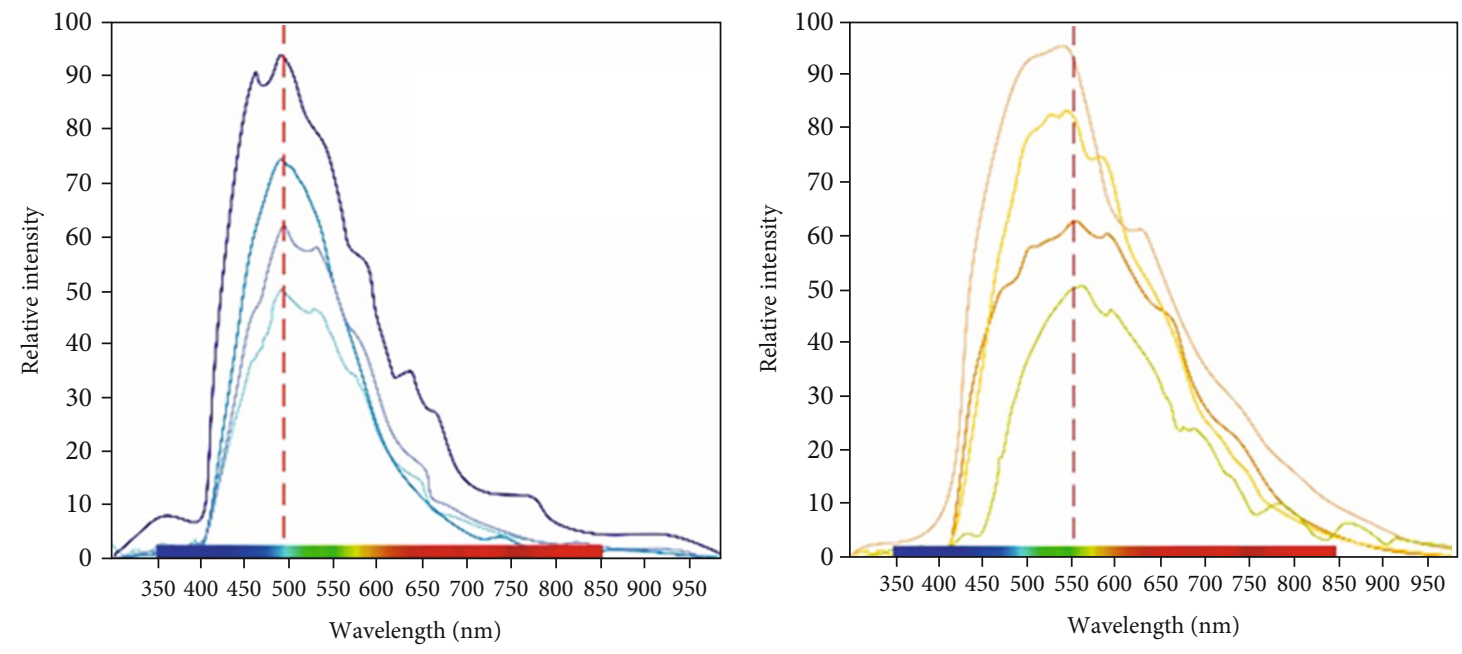

FIGURE 9: Microfluorescence spectra of oil inclusions with (a) blue and (b) yellow-white fluorescence colors.

the diagenesis processes that happened before and after the oil charge.

For Petrofacies A, before the first period of oil charge (late Silurian), with the rapid burial depth of the strata, the main diagenesis is mainly compaction. In addition, authigenic minerals are not developed apart from a small amount of chlorite in the form of grain coating (Figure $7(\mathrm{~d})$ ). In late Caledonian, a series of strike-slip faults and echelon faults were formed in the study area under the action of strong tectonic compression, which connected deep oil sources [27, 39]. During this period, the oil began to charge (Figure 11). Compared with the Petrofacies B sandstone, the Petrofacies A sandstone has higher porosity and permeability so that the latter is preferentially charged by oil. Due to continuous uplift and formation exposure, the first period of oil accumulation was destroyed and the crude oils gradually turned into black solid bitumen (Figures $8(\mathrm{a})$ and $8(\mathrm{~b})$ ). Before the first

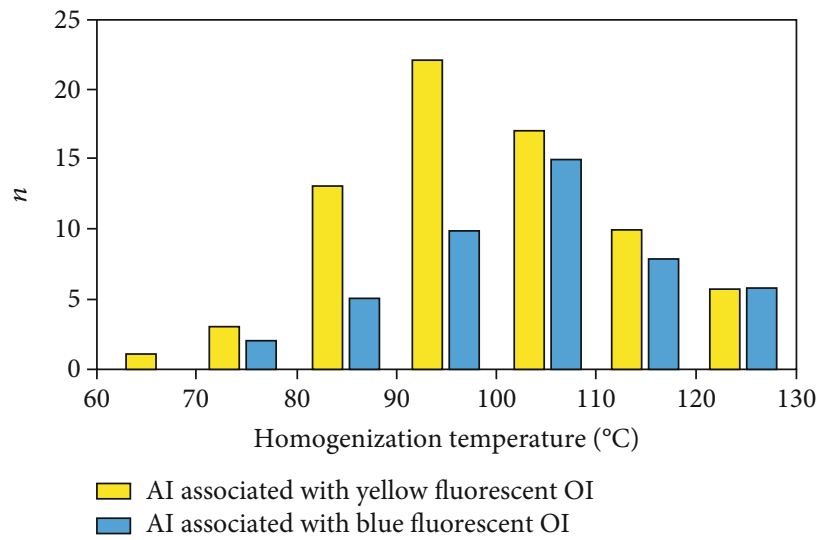

FIgURE 10: Homogenization temperatures of aqueous fluid inclusions associated with oil inclusions. Key: aqueous inclusion (AI), oil inclusion (OI). 


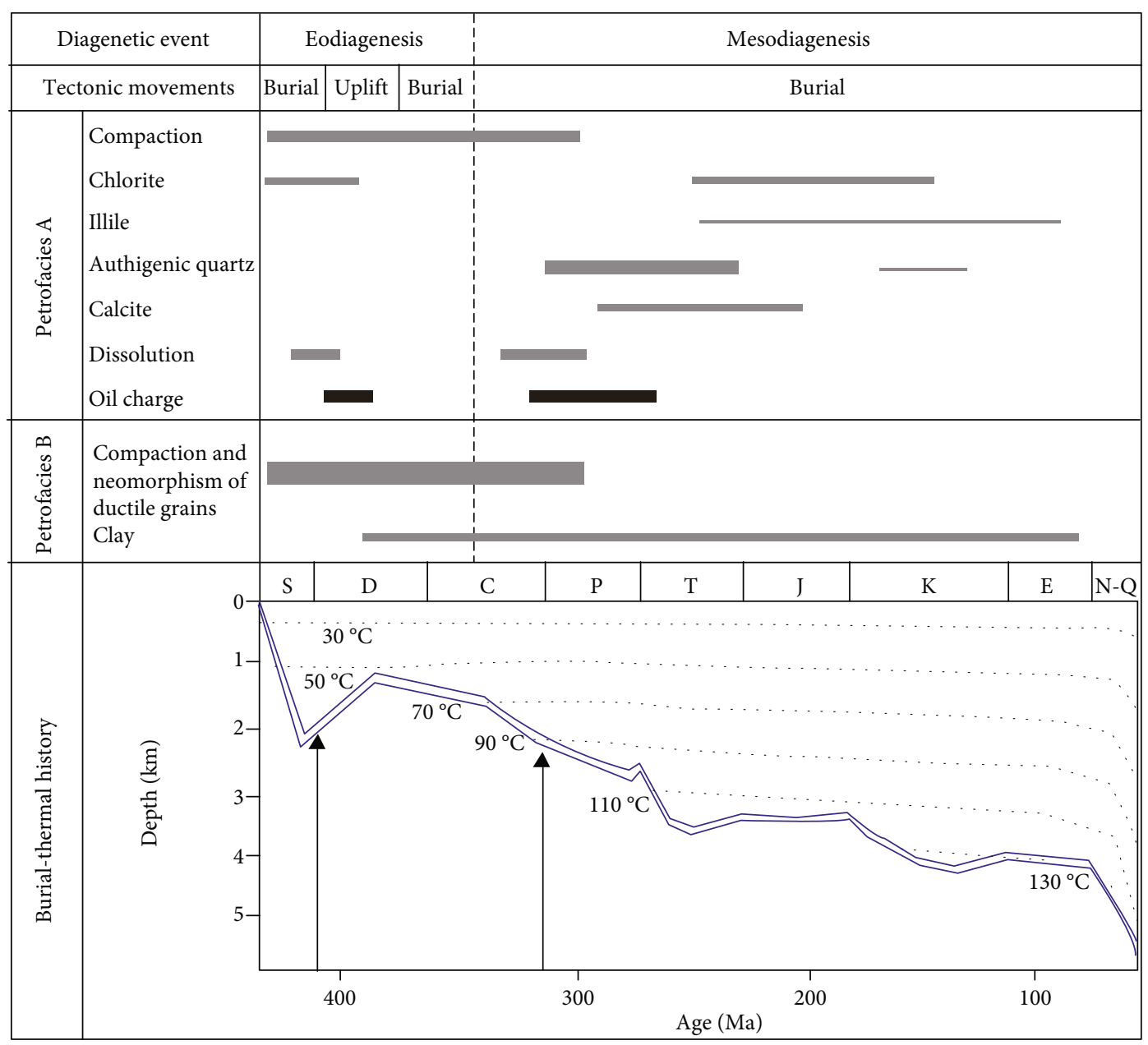

FIGURE 11: Diagenetic sequences and burial-thermal history of the Kepingtage Formation of S9 well block with timing of two period of oil charges.

period oil charge, the organic acid expelled during the maturation of organic matters plays a key role in the improvement of reservoir physical properties by dissolution. It is often seen that feldspar and other unstable aluminosilicate minerals are dissolved to form secondary pores and, then, filled with black solid bitumens (Figures 6(a), 7(a), 7(b), 8(a), and 8(b)). Based on petrological evidence, the diagenetic sequence of Petrofacies A sandstones before the first period of oil charge should be the following: chlorite film $\rightarrow$ dissolution $\rightarrow$ first period of oil charge and paleo oil reservoir destruction (Figure 11).

After the first period of oil charge, the Kepingtage Formation continued to be buried deep and the reservoir temperature continued to increase, a series of dissolution and cementation began to take place on a large scale, and the second period of oil charge occurred in the late Hercynian. At this time, Petrofacies B sandstone has already completed densification, but Petrofacies A still has medium porosity and permeability conditions. During this period, the source rock has entered into high maturity stage [24, 39]. Further dissolution of unstable minerals such as feldspar and rock fragments has taken place, creating secondary pores as migration pathways and storage spaces for oil migration and accumulation. Under UV light, it can be seen that dis- solved cleavage cracks of feldspar are filled with yellowwhite fluorescent oil (Figures 8(a) and 8(b)). But at the same time, under acidic conditions, the dissolution of feldspar and the transformation of some clay minerals provide the necessary sources for the precipitation of $\mathrm{SiO}_{2}$. And as the reservoir is buried deeper, the formation temperature gradually rises to the critical temperature of large-scale siliceous cementation [40-43]. In addition, the pressure dissolution between quartz grains strengthens. Large amount of quartz overgrowth begins to grow around the quartz grains (Figures $7(\mathrm{c})-7(\mathrm{~h})$ ). In addition to compaction, quartz overgrowth is an important pore reduction diagenesis event in the study area. When the quartz overgrowth is well developed, almost all the pore spaces are filled (Figure 6(h)). However, quartz overgrowth generally occurs after the yellow-white fluorescent oil charge, evidenced by the fact that in most cases, the black solid bitumens and the yellow-white fluorescent oil can be simultaneously captured in the same quartz overgrowth (Figures $8(\mathrm{e})$ and $8(\mathrm{f})$ ). It indicates that the crude oil charge occurs before or at least simultaneously with the quartz overgrowth. As the burial depth is further increased, the maturity of the source rock also increases, and oils with higher maturity are charged into the targe reservoirs along 


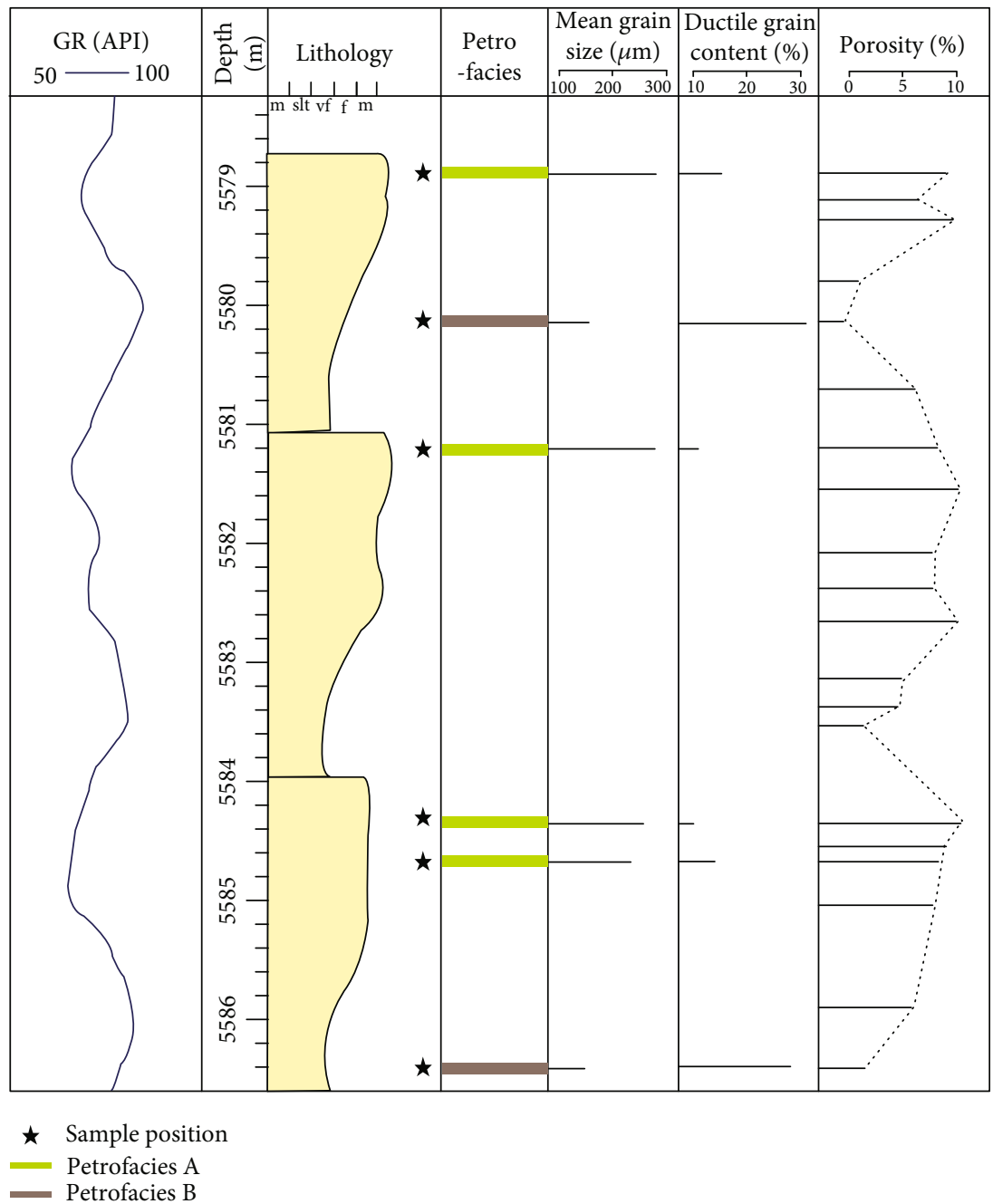

FIGURE 12: Vertical profile of S9 showing GR, lithology, grain size, ductile grain content, and petrofacies distribution.

the fault, and they appear as blue fluorescent oil asphaltenes in the reservoir. According to the emplacement relationship between diagenetic minerals and oil asphaltenes, it can be seen that the blue fluorescent oil inclusions are captured in the second phase of quartz overgrowth, while in the first phase of quartz overgrowth, the black solid bitumen and yellow-white fluorescent oil were captured (Figures 8(i) and $8(\mathrm{j})$ ), indicating that the blue fluorescent oil is charged later than the yellow-white fluorescent oil. With further increase in temperature and pressure, the consumption of organic acids together with the transform of clay minerals, the $\mathrm{pH}$ of the pore fluid increased and a small amount of calcite cement began to precipitate (Figures 7(c)-7(f)). In the calcite cement, solid asphalt and yellow-white fluorescent oil inclusions can be seen at the same time, indicating that its formation period is later than the two periods of oil charge.

In summary, after the second period of oil charge, the densification of the reservoir was intensified under further burial compaction and large scale of quartz overgrowth. The diagenetic sequence in this period is the following: dissolution $\rightarrow$ yellow-white fluorescent oil charge $\rightarrow$ quartz overgrowth $\mathrm{I} \rightarrow$ blue fluorescent oil charge $\rightarrow$ quartz overgrowth II $\rightarrow$ calcite cementation (Figure 11).

The content of ductile grains in Petrofacies B is very high (>20\%) (Table 1). The diagenesis is dominated by strong compaction and the porosity decreases rapidly. Except for some clay mineral precipitations, there are no other authigenic minerals in this kind of reservoir, which indicates that the pores of the reservoir have been destroyed in the early stage of shallow burial. According to the burial history of the study area (Figure 11), the burial depth of the reservoir has reached to 2000 meters before the first period of oil charge. Therefore, it is speculated that the reservoir has already become tight before the first period of oil charge (corresponding to the period of solid bitumen charge in Petrofacies A) and nearly no pore space is left for oil migration and accumulation.

5.3. Control of Sandstone Petrology on Diagenesis and Reservoir Quality. Petrofacies B sandstones and Petrofacies A sandstones coexist in the same bed and have an alternating distribution (Figure 12). While experiencing the same burial process, the two petrofacies had reached very different 


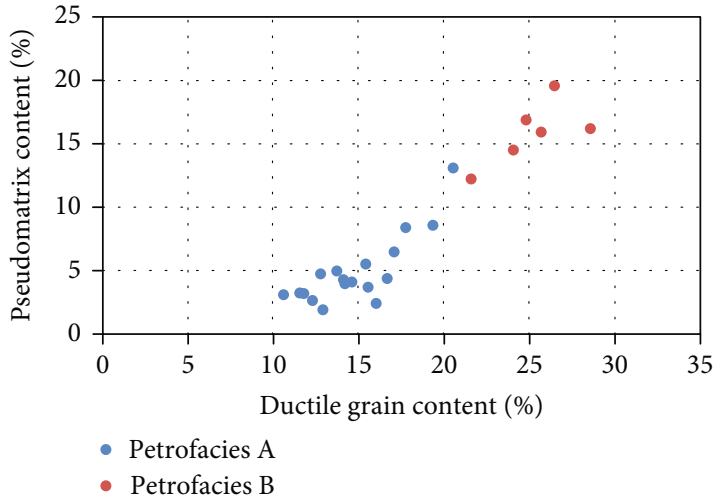

(a)

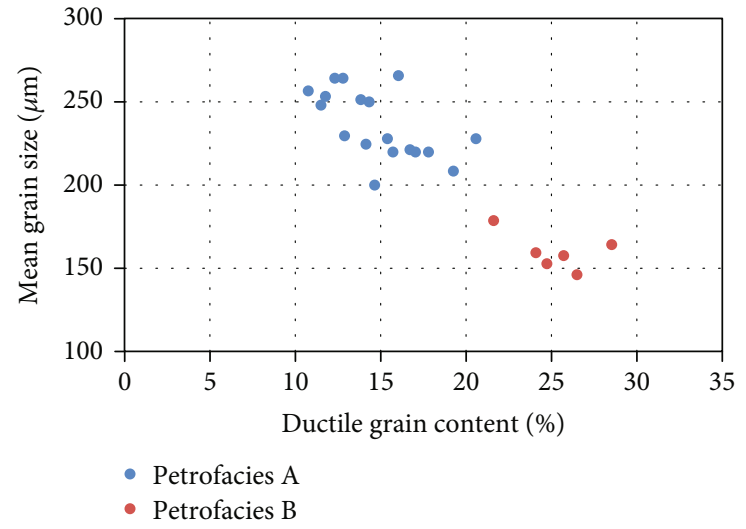

(b)

FIGURE 13: Cross plot showing the relationship between ductile grain content and pseudomatrix content (a) and mean grain size (b).

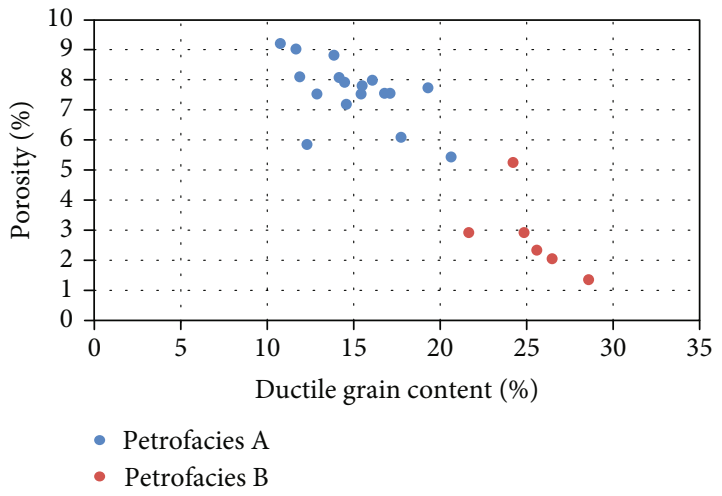

(a)

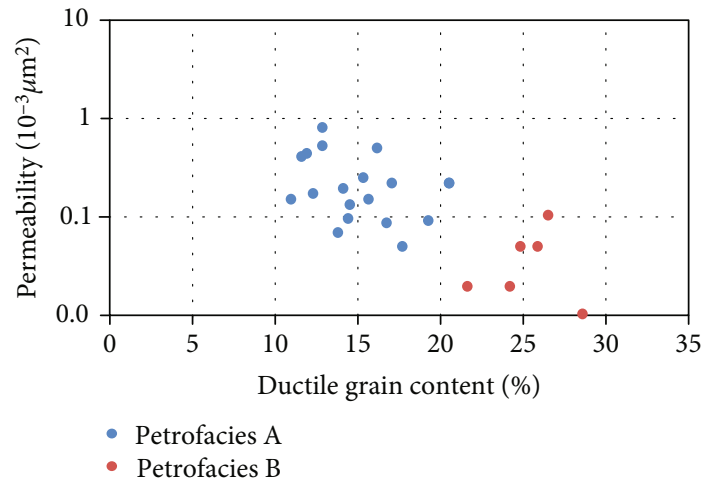

(b)

FIGURE 14: Relationships between reservoir ductile grain content and porosity (a) and permeability (b).

reservoir properties. Petrofacies A has better reservoir quality than Petrofacies B. This difference is mainly dominated by diagenesis changing the original pore structures of sandstones via ductile grain-induced compaction. Previous compaction physical simulation experiments show that the porosity reduction rate can reach to more than $80 \%$ at the equivalent burial depth of $1000 \mathrm{~m}$ in those reservoirs with the ratio of ductile grains to quartz grains of $1: 1$ [29]. Petrofacies $B$ have higher contents of ductile grains and thus experienced stronger compaction than Petrofacies A. In Petrofacies B sandstone, a certain number of ductile grains is squeezed into the pores under strong compaction to form pseudomatrix (Figures 6(i) and 6(j)). As shown in Figure 13(a), the higher the content of ductile grains, the higher the content of pseudomatrix, and the worse the reservoir physical properties (Figure 14).

The abundance of ductile grains is well correlated with grain size controlled by the sedimentary hydrodynamic conditions. The statistical results show that the finer the grain size of the reservoir, the higher the content of ductile grains (Table 1, Figure 12(b)). The Kepingtage Formation is mainly developed in shallow shelf sedimentary system in the study area [19]. As shown in Figure 12, the sand body of Kepingtage formation in the study area is actually formed by a vertical stack of a series of sand bars.
By detailed core description, combined with the classification of reservoir petrofacies, it is found that the Petrofacies A sandstone is mainly developed at the top of the sand bar, while the Petrofacies B sandstone is mainly developed at the middle and lower part of the sand bar where the depositional energy is low (Figure 12). Therefore, the physical properties of Petrofacies A are generally higher than that of Petrofacies B.

It is inferred that the hydrodynamic condition of the sedimentary environment controls the original grain composition of the reservoir, which in turn controls the intensity of compaction and whether hydrocarbon charge can occur. Therefore, the future work should focus on the study of sedimentary sand body architecture to predict the distribution of sand bodies with high content of ductile grains. On the basis of this, the reservoir heterogeneity model could then be built and oil and gas migration simulations could be carried out to predict the distribution of oil-bearing reservoirs.

\section{Conclusion}

(1) The sandstone of the Silurian Kepingtage Formation is dominated by litharenite sandstone. According to the difference in reservoir physical properties, oilbearing, the content of ductile grains, and the type 
and degree of diagenesis, it can be further divided into two types of petrofacies. The content of ductile grains in Petrofacies B sandstones is generally greater than $20 \%$, and the reservoirs are extremely tight under intense compaction. However, the content of ductile grains in Petrofacies A sandstone is low, and the reservoir has relatively better porosity and permeability

(2) The reservoirs of the Kepingtage Formation have generally experienced two periods of oil charge: late Caledonian and late Hercynian. After the early Caledonian oil charge, the formation was uplifted and eroded, and the paleo oil reservoir was destructed and the oil turned into black nonfluorescent solid bitumens. In the late Hercynian, two episodes of oil charges occurred in Petrofacies A sandstones. Under UV light, they are yellow-white fluorescent oils and blue fluorescent oils, respectively

(3) Due to strong compaction in Petrofacies B, severe densification has occurred before the first period of oil charge; therefore, no oil charge has occurred. On the contrary, various types of diagenetic events occurred in Petrofacies A sandstones, such as quartz overgrowth, calcite cementation, and dissolution. These authigenic minerals occurs alternately with hydrocarbon charge or sometimes they occur simultaneously

\section{Data Availability}

The data used to support the findings of this study are included within the article.

\section{Conflicts of Interest}

The authors declare that they have no conflicts of interest.

\section{Acknowledgments}

The study is financially supported by the Strategic Priority Research Program of the Chinese Academy of Sciences (XDA14010202) and the Joint Funds of the National Science Foundation of China (Grant No. U19B6003-02). Dr Yuanzhuang Chen from Sinopec is acknowledged for providing basic data and helpful suggestions. The lead editor Xiaorong Luo, Professor Likuan Zhang, and Dr. Binfeng Cao at IGGCAS are thanked for critical reviews and suggestions for this manuscript.

\section{References}

[1] B. Guoping and C. Binfeng, "Characteristics and distribution patterns of deep petroleum accumulations in the world," Oil \& Gas Geology, vol. 35, no. 1, pp. 19-25, 2014.

[2] X. Luo, Z. Likuan, F. Xiaofei, P. Hong, Z. Bo, and W. Zhaoming, "Advances in dynamics of petroleum migration and accumulation in deep basins," Bulletin of Mineralogy, Petrology and Geochemistry, vol. 35, no. 5, pp. 876-889, 2016.
[3] W. Yu, S. Jin, K. Wang, B. T. Zhang, J. Zhao, and X. W. Liu, "Distribution and accumulation of global deep oil and gas," Natural Gas Geoscience, vol. 23, no. 3, pp. 526-534, 2012.

[4] Z. Guangya, M. Feng, L. Yingbo et al., "Domain and theorytechnology progress of global deep oil \& gas exploration," Acta Petrolei Sinica, vol. 36, no. 9, p. 1156, 2015.

[5] J. Chengzao and P. Xiongqi, "Research processes and main development directions of deep hydrocarbon geological theories," Acta Petrolei Sinica, vol. 36, no. 12, pp. 1457-1469, 2015.

[6] S. Longde, Z. Caineng, R. Zhu et al., "Formation, distribution and potential of deep hydrocarbon resources in China," Petroleum Exploration and Development, vol. 40, no. 6, pp. 641-649, 2013.

[7] S. Morad, K. Al-Ramadan, J. M. Ketzer, and L. F. De Ros, "The impact of diagenesis on the heterogeneity of sandstone reservoirs: a review of the role of depositional facies and sequence stratigraphy," AAPG Bulletin, vol. 94, no. 8, pp. 1267-1309, 2010.

[8] M. A. K. El-Ghali, S. Morad, H. Mansurbeg et al., "Distribution of diagenetic alterations within depositional facies and sequence stratigraphic framework of fluvial sandstones: evidence from the Petrohan Terrigenous Group, Lower Triassic, NW Bulgaria," Marine and Petroleum Geology, vol. 26, no. 7, pp. 1212-1227, 2009.

[9] B. Cao, X. Luo, L. Zhang, F. Sui, H. Lin, and Y. Lei, "Diagenetic heterogeneity of deep sandstones and its relationship to oil emplacement: a case study from the middle Jurassic toutunhe formation in the Fukang Sag, central Junggar Basin (NW China)," Geofluids, vol. 2017, Article ID 4292079, 2017.

[10] B. Cao, X. Luo, L. Zhang, F. Sui, H. Lin, and Y. Lei, "Diagenetic evolution of deep sandstones and multiple-stage oil entrapment: a case study from the Lower Jurassic Sangonghe Formation in the Fukang Sag, central Junggar Basin (NW China)," Journal of Petroleum Science \& Engineering, vol. 152, pp. 136-155, 2017.

[11] X. Luo, Z. Likuan, L. Yuhong, H. Caizhi, S. Hui, and C. Binfeng, "Structural heterogeneity of reservoirs and its implication on hydrocarbon accumulation in deep zones," China Petroleum Exploration, vol. 21, no. 1, pp. 28-36, 2016.

[12] X. Luo, Z. Liqiang, Z. Likuan et al., "Heterogeneity of clastic carrier bed and hydrocarbon migration and accumulation," Acta Petrolei Sinica, vol. 41, no. 3, 2020.

[13] L. Mingjie, M. Zheng, F. Chaorong, and Z. Junyong, "Structural characteristics and Evolution of Tazhong low uplift," Journal of Xi'an Shiyou University, vol. 4, pp. 43-45, 2004.

[14] Z. Aihong, S. Yue, and Y. Feng, "Evolution and subsidencetectonic inversion history of Kartake paleo-uplift in Tazhong area of Tarim Basin," Journal of China University of Petroleum, vol. 35, no. 1, pp. 28-33, 2011.

[15] G. Yang, H. J. Yang, C. S. Luo, J. F. Han, and X. F. Wang, "Distribution and tectonic evolution of the paleozoic fault system, the north slope of Tazhong uplift, Tarim Basin," Acta Geologica Sinica, vol. 83, no. 8, pp. 1065-1073, 2009.

[16] D. Changhui, Z. Hongbo, and C. Lu, “The Paleozoic structural features and its evolution of in the Tazhong low uplift, Xinjiang," Geotectonica et Metallogenia, vol. 33, no. 1, pp. 148153, 2009.

[17] S. Guo and H. Keyan, "Silurian-Devonian sequence stratigraphy and favorable reservoir distribution in Tarim Basin," Acta Petrolei Sinica, vol. 3, pp. 44-50, 2007. 
[18] J. Jinhua, Z. Baomin, Z. Shihai, Z. Yuncheng, and L. Zhanyin, "Stratigraphy, sedimentary characteristics and lithofacies palaeogeography of the Silurian in Tarim Basin," Journal of Palaeogeography, vol. 3, pp. 339-352, 2006.

[19] L. Ruohan, M. Wang, J. Zaixing, and Y. Weili, "Development of sedimentary facies type in Silurian lower Kepingtage formation, Tahe area," Acta Sedimentologica Sinica, vol. 34, no. 2, pp. 326-335, 2016.

[20] X. Zhu, G. Wang, and Q. Xie, "Characteristics and distribution of depositional systems of Silurian in Tarim basin," Journal of the University of Petroleum, China, vol. 26, no. 3, pp. 5-11, 2002.

[21] R. Zhu, H. Guo, D. He et al., "Sand bodies and their reservoir quality in the Silurian Kepingtage formation in Tazhong area, Tarim Basin," Petroleum Exploration and Development, vol. 32, no. 5, pp. 16-19, 2005.

[22] Q. Gao, L. Liang, and S. Haibo, "Sedimentary characteristics of the lower members of the Silurian Kepingtage formation in shun 9 region, Tarim Basin," Northwestern Geology, vol. 48, no. 1, pp. 205-212, 2015.

[23] F. Y. Wang, S. C. Zhang, B. M. Zhang, Z. Y. Xiao, and C. W. Liu, "Maturity and its history of Cambrian marine source rocks in the Tarim Basin," Geochimica, vol. 32, no. 5, pp. 461-468, 2003.

[24] S. Longde, L. Yuejun, and J. Tongwen, "The Central Tarim lower uplift: a composite hydrocarbon accumulation play in the Tarim Basin, Nw China," Chinese Journal Of Geology, vol. 3, pp. 602-620, 2007.

[25] X. Han, S. Deng, L. Tang, and Z. Cao, "Geometry, kinematics and displacement characteristics of strike-slip faults in the northern slope of Tazhong uplift in Tarim Basin: A study based on 3D seismic data," Marine and Petroleum Geology, vol. 88, pp. 410-427, 2017.

[26] S. Deng, L. Huili, Z. Zhongpei, X. Wu, and J. B. Zhang, "Characteristics of differential activities in major strike-slip fault zones and their control on hydrocarbon enrichment in Shunbei area and its surroundings, Tarim Basin," Oil \& Gas Geology, vol. 39, no. 5, pp. 878-888, 2018.

[27] S. Deng, L. Huili, H. Jun, D. Y. Cui, and R. Zou, "Characteristics of the central segment of Shunbei 5 strike-slip fault zone in Tarim Basin and its geological significance," Oil \& Gas Geology, vol. 5, 2019.

[28] R. L. Folk, "Petrology of sedimentary rocks," Hemphills, vol. 182, 1974.

[29] E. D. Pittman and R. E. Larese, "Compaction of lithic sands: experimental results and applications," AAPG Bulletin, vol. 75, no. 8, pp. 1279-1299, 1991.

[30] K. J. Weber, "How heterogeneity affects oil recovery," in Reservoir Characterization, L. W. Lake and H. B. Carroll Jr., Eds., pp. 487-544, Academic Press, New York, NY, USA, 1986.

[31] G. Shanliang, X. Lu, and S. Haibo, "Reservoir characteristics and diagennesis evolution of tight sandstone reservoir of Shun9 well block," Petroleum Geology and Recovery Efficiency, vol. 21, no. $4,2014$.

[32] Z. Hanbing, P. Jun, S. Yang, M. Lu, Q. Xia, and B. Li, “Diagenesis and controlling factors of tight sandstone reservoirs: a case study of the lower member of Silurian Kepingtage formation in Shuntuoguole area, Tarim Basin," Petroleum Geology and Experiment, vol. 38, no. 4, pp. 543-550, 2016.

[33] X. S. Lu, Y. Song, S. B. Liu, B. L. Pu, N. Zhang, and B. S. Zhang, "Detailed analysis of fluid inclusions and its application in accumulation history research on Silurian reservoirs in Tazhong area, Tarim Basin," Journal of China University of Petroleum, vol. 36, no. 4, 2012.

[34] X. Zhu, C. Xuyun, and C. Zicheng, "Hydrocarbon accumulation mode of Shuntuo 1 well block in the Shuntuoguole lower uplift, Tarim Basin," Petroleum Geology and Experiment, vol. 39, no. 1, pp. 41-49, 2017.

[35] L. Luofu, Z. Jianzhang, Z. Shuichang, F. Jiahu, and X. Zhongyao, "Hydrocarbon filling ages and evolution ofthe Silurian asphalt sandstones in Tarim Basin," Acta Sedimentologica Sinica, vol. 18, no. 3, pp. 475-479, 2000.

[36] X. Wanlin, C. Honghan, Y. Lu et al., "Hydrocarbon charging history for Silurian reservoirs of Shuntuoguole block in the north slope of Tazhong uplift, Tarim Basin: constraints from fluid inclusion of Well Shun 9," Acta Petrolei Sinica, vol. 34, no. 2, pp. 239-246, 2013.

[37] H. Ping, H. Chen, S. C. George, C. Li, and S. Hu, "Relationship between the fluorescence color of oil inclusions and thermal maturity in the Dongying Depression, Bohai Bay Basin, China: Part 1. Fluorescence evolution of oil in the context of hydrous pyrolysis experiments with increasing maturity," Marine and Petroleum Geology, vol. 100, pp. 1-19, 2019.

[38] L. D. Stasiuk and L. R. Snowdon, "Fluorescence microspectrometry of synthetic and natural hydrocarbon fluid inclusions: crude oil chemistry, density and application to petroleum migration," Applied Geochemistry, vol. 12, no. 3, pp. 229-241, 1997.

[39] Q. Ma, S. Xuguang, L. Yulan, X. X. Zhu, S. J. Yang, and H. L. Li, "Characteristics of strike-slip fault and its controlling on oil in Shuntuoguole region, middle Tarim Basin," Petroleum Geology and Experiment, vol. 34, no. 2, pp. 120-124, 2012.

[40] M. R. Giles, S. Stevenson, S. V. Martin et al., "The reservoir properties and diagenesis of the Brent Group: a regional perspective," Geological Society, London, Special Publications, vol. 61, no. 1, pp. 289-327, 1992.

[41] K. Bjorlykke and P. K. Egeberg, "Quartz cementation in sedimentary basins,” AAPG Bulletin, vol. 77, no. 9, pp. 15381548, 1993.

[42] J. G. Gluyas, A. G. Robinson, D. Emery, S. M. Grant, and N. H. Oxtoby, "The link between petroleum emplacement and sandstone cementation," Geological Society, London, Petroleum Geology Conference Series, vol. 4, no. 1, pp. 1395-1402, 1993.

[43] R. H. Worden and S. Morad, "Quartz cementation in oil field sandstones: a review of the key controversies," Special Publication-International Association Of Sedimentologists, vol. 29, pp. 1-20, 2000. 